\title{
Functional Synaptic Integration of Forebrain GABAergic Precursors into the Adult Spinal Cord
}

\author{
DAlex Etlin, ${ }^{1}$ Joao M. Bráz, ${ }^{1}$ Julia A. Kuhn, ${ }^{1}$ Xidao Wang, ${ }^{1}$ Katherine A. Hamel, ${ }^{1}$ Ida J. Llewellyn-Smith, ${ }^{2}$ \\ and Allan I. Basbaum ${ }^{1}$ \\ ${ }^{1}$ Department of Anatomy, University of California, San Francisco, California 94158, and ${ }^{2}$ Cardiovascular Medicine, Human Physiology, and Centre for \\ Neuroscience, Flinders University, Bedford Park, South Australia 5042, Australia
}

Spinal cord transplants of embryonic cortical GABAergic progenitor cells derived from the medial ganglionic eminence (MGE) can reverse mechanical hypersensitivity in the mouse models of peripheral nerve injury- and paclitaxel-induced neuropathic pain. Here, we used electrophysiology, immunohistochemistry, and electron microscopy to examine the extent to which MGE cells integrate into host circuitry and recapitulate endogenous inhibitory circuits. Whether the transplants were performed before or after nerve injury, the MGE cells developed into mature neurons and exhibited firing patterns characteristic of subpopulations of cortical and spinal cord inhibitory interneurons. Conversely, the transplanted cells preserved cortical morphological and neurochemical properties. We also observed a robust anatomical and functional synaptic integration of the transplanted cells into host circuitry in both injured and uninjured animals. The MGE cells were activated by primary afferents, including TRPV1-expressing nociceptors, and formed GABAergic, bicucullinesensitive, synapses onto host neurons. Unexpectedly, MGE cells transplanted before injury prevented the development of mechanical hypersensitivity. Together, our findings provide direct confirmation of an extensive, functional synaptic integration of MGE cells into host spinal cord circuits. This integration underlies normalization of the dorsal horn inhibitory tone after injury and may be responsible for the prophylactic effect of preinjury transplants.

Key words: cell therapy; cell transplant; GABA; inhibitory interneurons; neuropathic pain; structural plasticity

Significance Statement

Spinal cord transplants of embryonic cortical GABAergic interneuron progenitors from the medial ganglionic eminence (MGE), can overcome the mechanical hypersensitivity produced in different neuropathic pain models in adult mice. Here, we examined the properties of transplanted MGE cells and the extent to which they integrate into spinal cord circuitry. Using electrophysiology, immunohistochemistry, and electron microscopy, we demonstrate that MGE cells, whether transplanted before or after nerve injury, develop into inhibitory neurons, are activated by nociceptive primary afferents, and form GABA-A-mediated inhibitory synapses with the host. Unexpectedly, cells transplanted into naive spinal cord prevented the development of nerve-injuryinduced mechanical hypersensitivity. These results illustrate the remarkable plasticity of adult spinal cord and the potential of cell-based therapies against neuropathic pain.

\section{Introduction}

Neuropathic pain can develop after peripheral or CNS damage and is characterized by ongoing, often burning pain and thermal

Received July 19, 2016; revised Aug. 26, 2016; accepted Aug. 31, 2016.

Author contributions: A.E., I.J.L.-S., and A.I.B. designed research; A.E., J.M.B., J.A.K., X.W., K.A.H., I.J.L.-S., and A.I.B. performed research;A.E., J.A.K., X.W., K.A.H., I.J.L.-S., and A.I.B. analyzed data; A.E. and A.I.B. wrote the paper.

This work was supported by the National Health and Medical Research Councl of Australia (GrantNS78326, GrantNS14627, and Project Grant 1025031), the Wellcome Trust of the UK, and the Facial Pain Research Foundation. We thank Izabela Panek, Rob Brownstone, Gregory Scherrer, and Dong Wang for their valuable advice on establishing the adult spinal cord slice preparation; Sophia Bardehle for help with the two-photon imaging; and Larry Ackerman for help with the electron microscopy.

The authors declare no competing financial interests.

This article is freely available online through the J Neurosci Author Open Choice option.

Correspondence should be addressed to Allan I. Basbaum, Department of Anatomy, University of California, 1550

4th Street, Box 2772, San Francisco, CA 94158. E-mail: allan.basbaum@ucsf.edu. and mechanical hypersensitivity (Basbaum et al., 2009; West et al., 2015). One proposed mechanism that contributes to the development of neuropathic pain is a loss of GABAergic inhibitory control at the level of the spinal cord dorsal horn (Ibuki et al., 1997; Zeilhofer, 2008; Basbaum et al., 2009). Among the proposed triggers of the GABAergic dysfunction are nerve-injuryinduced degeneration of GABAergic spinal interneurons (Moore et al., 2002; Scholz et al., 2005) or terminals (Lorenzo et al., 2014),

This is an Open Access article distributed under the terms of the Creative Commons Attribution License Creative Commons Attribution 4.0 International, which permits unrestricted use, distribution and reproduction in any medium provided that the original work is properly attributed. 
reduced primary afferent input to these interneurons (Polgár and Todd, 2008), microglial-induced alteration of GABAergic inhibition (Ferrini and De Koninck, 2013), decreased spinal release of GABA (Lever et al., 2003), and downregulation of either the GABA biosynthetic enzyme glutamic acid decarboxylase (GAD) or GABA receptors (Eaton et al., 1998; Fukuoka et al., 1998).

Given the similarities between the etiology of neuropathic pain and epilepsy (Loeser et al., 1968), it is not surprising that anticonvulsant pharmacological restoration of GABAergic inhibition reduces mechanical hypersensitivity in models of neuropathic pain (Knabl et al., 2008; Munro et al., 2009; Paul et al., 2012). The utility of systemic administration of anticonvulsants, however, is limited in part because of adverse motor and cognitive side effects. An alternative is to treat the underlying cause of the pain by repairing dysfunctional GABAergic inhibitory circuits. To this end, several studies transplanted GABA-synthesizing cells into the spinal cord (Mukhida et al., 2007; Jergova et al., 2012) or the spinal cord CSF (Ibuki et al., 1997; Eaton et al., 1999) and reported significant reduction of the hypersensitivity associated with peripheral nerve injury. We demonstrated that transplantation into the adult mouse spinal cord of embryonic cortical cells from the medial ganglionic eminence (MGE), precursors of neocortical GABAergic interneurons, reverses the mechanical hypersensitivity that occurs in spared nerve injury (SNI) and chemotherapy-induced models of neuropathic pain (Bráz et al., 2012; Bráz et al., 2015).

In contrast, MGE cells transplanted into naive animals did not alter nocifensive behaviors in the formalin test, a model of tissueinjury-induced postoperative pain in which dorsal horn inhibitory neurons are sensitized, but GABAergic function is not compromised (Bráz et al., 2012). Moreover, preinjury transplants did not alter baseline $(\mathrm{BL})$ mechanical pain thresholds. Because GABA agonists increase pain thresholds (Hammond and Drower, 1984) and are effective in the formalin test (Kaneko et al., 2000), these results were unexpected. We hypothesized that either the transplants only survive in the setting of nerve damage or they survive, but do not integrate sufficiently, in normal, uninjured animals. Here, we used electrophysiology, immunohistochemistry, and electron microscopy to examine the integration of MGE cells that were transplanted either before or after SNI into the dorsal horn of adult mice. In both conditions, we found comparable synaptic integration into and regulation of host neurons. In addition, in behavioral studies, when the transplants were performed before peripheral nerve injury, we observed a remarkable transplant-mediated prevention of mechanical hypersensitivity.

\section{Materials and Methods}

Mouse lines. Experimental procedures were reviewed and approved by the Institutional Animal Care and Use Committee at the University of California-San Francisco. All transplants were performed on male mice (6-8 weeks old) with the same genetic background as the MGE donors (CD1xC57BL/6J). For some experiments, MGE cells were dissected from double-transgenic I12b-ChR2 mice, which express the light-sensitive cation channel Channelrhodopsin 2 (ChR2) selectively in the forebrain. These mice were generated by crossing mice that express Cre recombinase under the control of the I12b enhancer (I12b-Cre; Potter et al., 2009) with mice that express a floxed ChR2 cDNA under the control of the Rosa26 promoter (Ai32; Madisen et al., 2012; Jackson Laboratories). For some experiments, we transplanted MGE cells into the spinal cord of double-transgenic TRPV1-ChR2 mice that were generated by crossing mice that express Cre under the TRPV1 promoter (TRPV1-Cre; Cavanaugh et al., 2011) with Ai32 mice.

Transplantation of MGE cells. Previous reports provide a detailed description of the harvesting and transplantation procedures (AlvarezDolado et al., 2006; Bráz et al., 2012). Briefly, we dissected MGE cells from transgenic mice that express GFP under the control of the GAD67 promoter (Gadltml.1Tama; Tamamaki et al., 2003). Naive, 5- to 6-week-old mice were anesthetized by an intraperitoneal injection of ketamine $(60 \mathrm{mg} / \mathrm{kg} / \mathrm{xylazine} 8 \mathrm{mg} / \mathrm{kg})$ and a dorsal hemilaminectomy exposed two segments of lumbar spinal cord. After the dura was incised and reflected, we used a glass micropipette to inject a suspension containing $5 \times 10^{4} \mathrm{MGE}$ cells into the dorsal horn on one side of the spinal cord. The injections were targeted to the deep dorsal horn $(200 \mu \mathrm{m}$ from the dorsal cord surface). We made three to four injections (100 $\mathrm{nL}$ each) between the medial border of the L5 dorsal root entry zone and the midline. The overlying muscle and skin were closed and the animals were allowed to recover before they were returned to their home cages. The mice were either used for recordings 3 weeks after surgery or aldehyde-perfused for electron microscopy 5-6 weeks after surgery.

Spinal cord slice preparation. Two different solutions for dissection and recording were prepared on the day of the experiment. The composition of the dissection solution was as follows (in $\mathrm{mm}$ ): sucrose 215, K-gluconate 3.0, $\mathrm{NaH}_{2} \mathrm{PO}_{4}-\mathrm{H}_{2} \mathrm{O} 1.25, \mathrm{NaHCO}_{3} 26$, glucose $10, \mathrm{MgSO}_{4}$ 4.0, $\mathrm{CaCl}_{2}-2 \mathrm{H}_{2} \mathrm{O} 1.0$, and kynurenic acid 1.0 (Takazawa and MacDermott, 2010). The composition of the recording solution was as follows (in mM): $\mathrm{NaCl} 217, \mathrm{KCl} 3.0, \mathrm{NaH}_{2} \mathrm{PO}_{4}-\mathrm{H}_{2} \mathrm{O} 1.25, \mathrm{NaHCO}_{3} 26, \mathrm{MgCl}_{2} 1.0$, and $\mathrm{CaCl}_{2}-2 \mathrm{H}_{2} \mathrm{O}$ 2.0. The $\mathrm{pH}$ of both solutions was adjusted with $\mathrm{KOH}$ to 7.4 and all solutions were continuously bubbled with $95 \% \mathrm{O}_{2} / 5 \% \mathrm{CO}_{2}$. For recording of MGE evoked IPSCs (eIPSCs) from host neurons after nerve injury, the composition of the dissection solution was as follows (in mM): NMDG 93, $\mathrm{KCl} 2.5, \mathrm{NaH}_{2} \mathrm{PO}_{4} 1.2, \mathrm{NaHCO}_{3} 30$, HEPES 20, glucose 25 , sodium ascorbate 5 , thiourea 2 , sodium pyruvate $3, \mathrm{MgSO}_{4} 7 \mathrm{H}_{2} \mathrm{O} 10$, and $\mathrm{CaCl}_{2}-2 \mathrm{H}_{2} \mathrm{O}$ 0.5. The composition of the recovery solution was as follows (in mM): $\mathrm{NaCl} 92, \mathrm{KCl} 2.5, \mathrm{NaH}_{2} \mathrm{PO}_{4} 1.2, \mathrm{NaHCO}_{3} 30$, HEPES 20 , glucose 25 , sodium ascorbate 5 , thiourea 2 , sodium pyruvate 3 , $\mathrm{MgSO}_{4} 7 \mathrm{H} 2 \mathrm{O} 2$, and $\mathrm{CaCl}_{2}-2 \mathrm{H}_{2} \mathrm{O} 2$ (Moyer and Brown, 1998; Tanaka et al., 2008). On the day of the experiment, $2-3$ weeks after transplantation of embryonic MGE cells, 8- to 9-week-old mice were killed with an overdose of Avertin (Sigma-Aldrich). After transcardial perfusion with $8.0 \mathrm{ml}$ of dissection solution, the spinal column (T6-Co1) was quickly removed and placed, ventral surface upward, in a Petri dish coated with silicone (Sylgard; Cole-Palmer) and filled with ice-cold dissection solution. Under a stereoscope (AmScope), the spinal cord was exposed by removing the appropriate vertebrae and dissected out using fine scissors and forceps. Because scar tissue that forms after transplantation can result in adherence of spinal cord tissue to overlying bone, particular care was taken when separating the injected segments. Next, the dura and ventral nerve roots were removed from the lumbar segments, which were then embedded in 5\% low-melting-point agarose (Invitrogen). The agarose block containing the spinal cord was mounted in a Vibratome (VT1200; Leica) bath filled with ice-cold dissection solution and six to eight transverse or parasagittal sections were cut. The sections were transferred to a glass beaker containing heated $\left(37^{\circ} \mathrm{C}\right)$ recording or recovery solution. Because the viability of the dorsal horn and MGE cells deteriorated substantially if the sections were not placed into recording solution within $20 \mathrm{~min}$ of the mouse being killed, we found that rapid isolation of the cord and sectioning proved critical.

Electrophysiological recordings. The sections recovered in heated solution $\left(37^{\circ} \mathrm{C}\right)$ for at least $1 \mathrm{~h}$ before use. Next, the sections were transferred to a recording chamber (Automate Scientific) under an upright fluorescence microscope (E600FN; Nikon) and superfused with recording solution at a rate of $1.0 \mathrm{ml} / \mathrm{min}$. Sections were viewed with a CCD digital camera (Hamamatsu or DAGE-MTI). The transparent appearance of lamina II of the superficial dorsal horn was readily apparent under nearinfrared (IR) illumination; GFP-expressing MGE cells were obvious under $460 \mathrm{~nm}$ illumination emitted by an LED light source (Sutter Instrument). Patch pipettes were pulled on a horizontal pipette puller (Sutter Instrument) from thin-walled, fire-polished, borosilicate glass filaments to yield an impedance of 6-8 M $\Omega$. The composition of the pipette solution was as follows (in $\mathrm{mm}$ ): K-methane sulfonate $140, \mathrm{NaCl}$ 10, $\mathrm{CaCl}_{2}$ 1.0, EGTA 1.0, HEPES 10, Mg-ATP 5.0, and NaGTP 0.5 and included $5.0 \mathrm{mg} / \mathrm{ml}$ of Biocytin (Sigma-Aldrich) to allow for subsequent intracellular filling of the recorded cells. 
Cells were visualized under near-IR differential interference contrast illumination and approached with a micromanipulator (Sutter Instrument) while monitoring the resistance in voltage-clamp mode using the "Membrane Test" module of pClamp10 software (Molecular Devices). To prevent clogging of the tip, we applied positive pressure to the pipette via a $1.0 \mathrm{ml}$ syringe. After a seal was established with a cell, we ruptured its membrane by gently applying negative pressure to the pipette to establish a whole-cell configuration. We did not correct for leak or junction potentials. Current and voltage signals were amplified using a DC amplifier (MultiClamp 700) and digitized using Digidata 1440a system (Molecular Devices) at $10 \mathrm{kHz}$ and stored for subsequent offline analysis. In some experiments, synaptic responses were evoked in MGE cells by electrical stimulation of the attached dorsal root that was placed in a suction electrode.

Optogenetic stimulation and drug administration. In some experiments, we used an LED (460 nm; Sutter Instrument) to excite the neurons or terminals that expressed ChR2. The light pulse was delivered through the $40 \times$ objective of the microscope with a pulse duration of $5-20 \mathrm{~ms}$ at 0.2 , $0.5,1,2$, and $5 \mathrm{~Hz}$. All drugs were purchased from Sigma-Aldrich and stored as a stock solution at $-20^{\circ} \mathrm{C}$. The drugs were applied through a perfusion system equipped with pinch valves (Automate Scientific).

Immunohistochemistry. After completion of the recordings, the pipette was gently retracted to avoid traumatic extraction of the patched cell. The sections were fixed overnight in $4 \%$ paraformaldehyde in PBS, followed by overnight cryoprotection in phosphate-buffered $30 \%$ sucrose. Immunostaining and streptavidin (SA) staining were performed on intact, freefloating 350- to $400-\mu \mathrm{m}$-thick sections or in $25-\mu \mathrm{m}$-thick cryosections of the spinal cord slice. After immunostaining, the sections were visualized with a confocal (LSM700; Zeiss) or two-photon microscope (Olympus). The low- and high-magnification micrographs are presented as maximum $Z$-projections and single plane images, respectively.

Primary antibodies were as follows: rabbit anti-GFP (1:2000; Molecular Probes), mouse anti-NF200 (1:10,000; Sigma-Aldrich), rabbit antiperipherin (1:4000; Abcam), and guinea-pig anti-TRPV1 (1:7000, gift from Dr. David Julius). Secondary antibodies were as follows: Alexa Fluor 488 goat anti-rabbit (1:700; Molecular Probes), and SA 594 (1: 5000; Molecular Probes).

Electron microscopy. Mice with 5- to 6-week-old MGE transplants were deeply anesthetized with Avertin and then perfused with tissue culture medium followed by phosphate-buffered $4 \%$ formaldehyde, $0.3 \%$ glutaraldehyde. After postfixation overnight at $4^{\circ} \mathrm{C}$, cord segments containing transplants from two to three mice were embedded in albumin gelatin (Llewellyn-Smith et al., 2007) and cut on a Vibratome at $50 \mu \mathrm{m}$.

The Vibratome sections were processed for detection of GFP at the electron microscope level. After washing for $2 \mathrm{~h}$ in $50 \%$ ethanol (Llewellyn-Smith and Minson, 1992), the sections were incubated for 30 min in 10\% normal horse serum (NHS; Invitrogen) diluted with TrisPBS (TPBS), then in 1:10,000 or 1:20,000 chicken anti-GFP (Abcam) in $10 \%$ NHS-TPBS. The sections were subsequently exposed to 1:500 biotinylated donkey anti-chicken IgG in 1\% NHS-TPBS (Jackson ImmunoResearch) and then to 1:1500 ExtrAvidin-horseradish peroxidase (Sigma-Aldrich) in TPBS. Incubations in immunoreagents were for $3 \mathrm{~d}$ at room temperature on a shaker; sections were washed $3 \times 30 \mathrm{~min}$ between incubations. To detect GFP immunoreactivity in transplanted MGE cells, we used a nickel-intensified diaminobenzidine reaction and hydrogen peroxide generated by glucose oxidase (Llewellyn-Smith et al., 2005). After washing, sections containing GFP-immunoreactive neurons were osmicated, stained en bloc with aqueous uranyl acetate, dehydrated through graded acetone solutions and propylene oxide, and infiltrated with Durcupan resin (Sigma-Aldrich). Finally, sections were embedded on glass slides under Aclar (Electron Microscopy Sciences) coverslips and polymerized at $60^{\circ} \mathrm{C}$ for at least $48 \mathrm{~h}$. Dorsal horn regions containing transplanted GFP neurons were re-embedded on blank blocks under glass coverslips and repolymerized. Ultrathin sections were collected on copper mesh grids, stained with aqueous uranyl acetate, and examined with a JEOL 100CXII transmission electron microscope.

SNI. To produce mechanical hypersensitivity in a model that mimics a neuropathic pain condition, we used the mouse SNI model (Shields et al.,
Table 1. Intrinsic properties of post-SNI and pre-SNI MGE cells

\begin{tabular}{|c|c|c|c|}
\hline & Post-SNI & Uninjured & $\begin{array}{l}\text { Mann- } \\
\text { Whitney } \\
\text { test }(p)\end{array}$ \\
\hline No. of mice & 7 & 16 & \\
\hline $\begin{array}{l}\text { Membrane potential } \\
(\mathrm{mV})\end{array}$ & $-55.52 \pm 1.89(n=21)$ & $-63.56 \pm 1.7(n=32)$ & 0.003 \\
\hline $\begin{array}{l}\text { Input resistance } \\
\qquad(\mathrm{M} \Omega)\end{array}$ & $336.55 \pm 55.05(n=21)$ & $399.36 \pm 43.53(n=32)$ & 0.391 \\
\hline Capacitance (pF) & $156.73 \pm 33.15(n=21)$ & $126.16 \pm 13(n=32)$ & 0.274 \\
\hline $\begin{array}{l}\text { Firing frequency } \\
\qquad(\mathrm{Hz})\end{array}$ & $23.4 \pm 4.61(n=8)$ & $32.4 \pm 3.17(n=10)$ & 0.191 \\
\hline AP threshold (mV) & $-38.64 \pm 7.64(n=13)$ & $-43.5 \pm 3.5(n=29)$ & 0.053 \\
\hline AP amplitude (mV) & $43.73 \pm 4.47(n=13)$ & $60.6 \pm 3.1(n=29)$ & 0.013 \\
\hline AP half-width (ms) & $2.55 \pm 0.41(n=13)$ & $1.7 \pm 0.2(n=29)$ & 0.002 \\
\hline $\begin{array}{l}\text { AP AHP amplitude } \\
(\mathrm{mV})\end{array}$ & $6.05 \pm 1.93(n=11)$ & $2.6 \pm 2.2(n=29)$ & 0.274 \\
\hline Tonic & $42.1 \%$ & $67.7 \%$ & $\chi^{2}=13.47$ \\
\hline Single & $36.8 \%$ & $6.5 \%$ & \\
\hline Initial bursting & 0 & $12.9 \%$ & \\
\hline Irregular & $21.1 \%$ & $3.2 \%$ & $p=0.009$ \\
\hline Delayed & 0 & $9.7 \%$ & \\
\hline
\end{tabular}

2003), in which two of the three branches of the sciatic nerve are transected, sparing the tibial nerve.

Behavioral analyses. Mechanical sensitivity was assessed by placing the mouse on an elevated wire mesh grid and stimulating the hindpaw with von Frey filaments using the up-down paradigm to define mechanical withdrawal threshold (Chaplan et al., 1994). Animals were tested both before and after SNI and before and after MGE transplantation (see Results). In the pre-SNI transplant behavioral experiments, mice transplanted with cell medium served as a control and the investigator performing the behavioral tests was blinded to treatment (cell medium or MGE injection). In these pre-SNI experiments, the MGE-transplanted animals were killed 6 weeks after transplant, after which the spinal cord was immunostained for the presence of $\mathrm{GFP}^{+}$cells. Only after successful transplant was confirmed (defined as having at least one $\mathrm{GFP}^{+}$cell per section) were the behavioral results analyzed. Importantly, the investigator performing the anatomical analysis was not the investigator who performed the behavior analysis. In the post-SNI experiments, mechanical thresholds of the unaffected side served as the control.

Data analysis. Intrinsic membrane properties and action potential (AP) properties of the recorded neurons were calculated using customwritten MATLAB scripts (MathWorks). Resting membrane potential $\left(V_{\mathrm{m}}\right)$, cell capacitance $\left(C_{\mathrm{m}}\right)$, and series resistance $\left(R_{\mathrm{m}}\right)$ were inferred from an $I-V$ curve constructed by recording the responses of cells to 500 $\mathrm{ms}$ depolarizing current injections of increasing intensity ( $-60-100 \mathrm{pA})$ in current-clamp mode. The threshold for AP generation (Table 1, "AP threshold") was extracted from the first sweep in which an AP was observed and was defined as the point of abrupt change in amplitude from baseline (BL) voltage in response to a current step. The "AP peak amplitude" was calculated as the difference between the maximal and threshold amplitudes. The "AP half-width" was calculated as the time difference between two points at 50\% maximal amplitude on the rising and the decaying phase of the AP. The "afterhyperpolarization (AHP) amplitude" was defined as the difference between the threshold and the minimum voltage.

For experiments in which recordings were made from host neurons, we calculated the density of the optogenetically evoked currents by normalizing the area under curve first to the individual cell's capacitance $\left(C_{\mathrm{m}}\right)$ and then to the density of the BL current. Statistical analyses were performed using GraphPad Prism software. The data are presented as mean \pm SEM. $p$-values $<0.05$ were considered statistically significant. 


\section{Results}

MGE cells transplanted after peripheral nerve injury exhibit intrinsic properties characteristic of GABAergic interneurons Our first set of experiments followed upon our finding that transplantation of MGE cells after a peripheral nerve injury can reverse the injury-induced mechanical hypersensitivity. Ten male mice, 5-6 weeks old, underwent SNI surgery and were transplanted with MGE cells 1 week later (post-SNI MGE cells). All mice in this and other SNI experiments consistently exhibited mechanical allodynia of the paw ipsilateral to the injury beginning $3 \mathrm{~d}$ after SNI (Fig. 1A, 2-way ANOVA $F_{(3,54)}=63.57, p<0.0001$, followed by Tukey post hoc test, BL ipsilateral vs 3 d ipsilateral: $p<0.0001 ; 3 \mathrm{~d}$ ipsilateral vs 3 weeks ipsilateral, $p<0.0001$ ). To ensure that the electrophysiological experiments were performed when the transplant was fully effective, ideally, we would have waited until the mechanical allodynia was completely reversed, which occurs at $\sim 4$ weeks after transplant (Bráz et al., 2012). However, this would have required performing the experiments on fairly old mice, in which it is much more difficult to obtain highquality spinal cord slice recordings. Therefore, we made the recordings shortly after we observed a significant, albeit incomplete, recovery of the mechanical thresholds compared with the thresholds measured $3 \mathrm{~d}$ after the transplant (Fig. $1 \mathrm{~A}$ ). Therefore, 3-4 weeks after the SNI (and 2 weeks after the MGE transplant), the mice were killed and transverse lumbar cord slices $(350-400 \mu \mathrm{m})$ containing the transplants were prepared for whole-cell patch-clamp recordings from the GFPpositive cells (Fig. 1B). Recordings were made from cells in the superficial dorsal horn as well as in the nucleus proprius (laminae III-VI; Fig. 1C).

We obtained stable recordings from 24 post-SNI MGE cells and examined spontaneous activity in 12 of these cells. Each of these cells had varying levels of spontaneous EPSPs $(52.5 \pm 12.3$ EPSPs/10 s) and $10(83 \%)$ exhibited spontaneous firing (18 \pm 7.5 APs/min). Nineteen of the 24 cells (79\%) generated at least one $\mathrm{AP}$ in response to a depolarizing current injection.

Previous studies categorized CNS interneurons based on their firing pattern in response to a depolarizing current step. In general, these patterns identify excitatory or inhibitory interneurons, confirmed by either neurotransmitter content or expression of GAD67. The superficial dorsal horn (Heinke et al., 2004; Schoffnegger et al., 2006; Yasaka et al., 2010), as well as the great majority of cortical (Kawaguchi and Kubota, 1997) inhibitory neurons, exhibit a tonic firing pattern with minimal or no frequency adaptation. Here, we characterized intrinsic properties by introducing a series of incrementally increasing depolarizing current steps into the MGE cells in currentclamp mode.

Eight of the $19(42.1 \%)$ firing MGE cells exhibited a tonic firing pattern (Fig. 1D,E, Table 1). Seven of the 19 (36.8\%) MGE cells exhibited a "single" or "initial bursting" pattern, also characteristic of subsets of CNS inhibitory interneurons (Schoffnegger et al., 2006); 4/19 (21\%) exhibited the "irregular" firing pattern. Based on these experiments, we conclude that immature MGE cells transplanted into the adult spinal cord develop into functional neurons and exhibit activity patterns predominantly characteristic of inhibitory interneurons.

\section{Nociceptive primary afferent fibers activate post-SNI MGE cells}

We demonstrated previously that triggering a transneuronal anterograde tracer in primary afferents resulted in transfer of the tracer from the afferents to the transplanted MGE cells. Based on these findings and on noxious stimulation-induced Fos in transplanted neurons, we concluded that primary afferents likely formed presynaptic connections with the transplanted neurons (Bráz et al., 2012). Here, we tested this hypothesis directly in transverse spinal cord slices with an attached dorsal root. After electrical stimulation of primary afferents through an attached dorsal root (Fig. 1F, $n=2$ mice), we observed evoked responses in 4/6 MGE cells (Fig. 1G). Based on the rheobase (100-500 $\mu \mathrm{A}$ ), on the latency of the evoked responses $(<2 \mathrm{~ms}$ for A $\delta$ fibers, $>5$ $\mathrm{ms}$ for $\mathrm{C}$ fibers), and on the presence of jitter $(<2 \mathrm{~ms}$ variability for monosynaptic connectivity) and failures, we determined that 1 cell received monosynaptic A $\delta$-fiber innervation (Fig. $1 G a$ ), 2 received only polysynaptic C-fiber innervation (Fig. $1 G b$ ), and 1 received both monosynaptic $\mathrm{A} \delta$-fiber and polysynaptic C-fiber inputs (Fig. 1Gc). Although the sample in these experiments is limited, we conclude that at least some MGE cells transplanted after nerve injury can be activated by small-diameter primary afferents.

\section{Post-SNI MGE cells form functional GABAergic synapses on host neurons}

As noted above, we attribute the therapeutic effect of transplanted MGE cells against the mechanical hypersensitivity produced in neuropathic pain models to their restoration of inhibitory GABAergic tone in the dorsal horn. Consistent with this proposed mechanism, we recently reported that transplants of MGE cells from mice with a deletion of the vesicular GABA transporter (VGAT), the neurons of which cannot transport GABA into synaptic vesicles and survive in the host, have no effect on mechanical or heat hyperalgesia in the paclitaxel pain model (Bráz et al., 2015). That finding argued strongly that GABA release from the transplants is required for the reestablishment of inhibitory controls. Here, we tested this hypothesis directly.

In these studies, we recorded eIPSCs from host dorsal horn neurons in transverse and parasagittal slices prepared from spinal cords of 5 post-SNI mice that were transplanted $7 \mathrm{~d}$ after injury with MGE cells that express ChR2 under control of the ROSA26 promoter (see Materials and Methods). In these mice, a pulse of blue light $(20 \mathrm{~ms})$ activated a large percentage of the transplanted MGE cells in the slice, which reliably produced eIPSCs in the host neurons from which recordings were made (Fig. $1 H$ ). To minimize the contribution of inward currents and to increase the anion driving force, we briefly clamped the membrane potential of the recorded neurons at $+10 \mathrm{mV}$.

Under these conditions, we recorded optogenetically evoked IPSCs in 14 of 32 randomly identified laminae II-V host neurons ( $n=5$ mice; Fig. $1 I, \mathrm{BL})$. The amplitude of these IPSCs was $-177.28 \pm 24.5 \mathrm{pA}$ and the latency was $6.3 \pm 0.5 \mathrm{~ms}$. Control stimulation with green light did not evoke responses in any of the cells tested (data not shown). In eight of the 14 cells, the recording was sufficiently stable to allow pharmacological analysis of the IPSCs. In all of these cells, the GABA-A receptor antagonist bicuculline $(20 \mu \mathrm{M})$ significantly reduced the IPSCs (Fig. 1I,J, Bic, percentage reduction: $78.6 \pm 0.07 \%$ vs BL; Friedman test, Friedman statistic $=16$, groups $=3$, subjects $=8, p<0.0001$, Dunn's multiple-comparisons test, $p<0.0002$ for BL vs Bic). After washout, the membrane potential recovered to $55.5 \pm 8.3 \%$ of the $\mathrm{BL}$ levels (Fig. 1I,J, wash).

Because previous studies demonstrated a contribution of presynaptic GABA-B receptors to modulation of nociceptive inputs (Riley et al., 2001; Fukuhara et al., 2013), we examined the effect of GABA-B receptor blockade on the optogenetically evoked IPSCs 
A

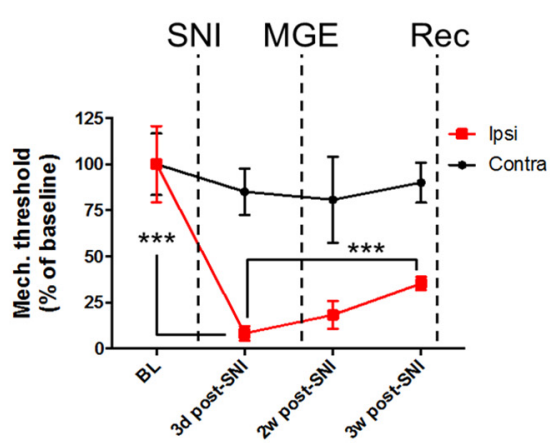

D

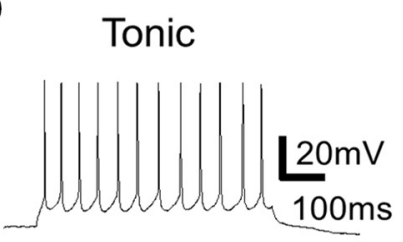

B

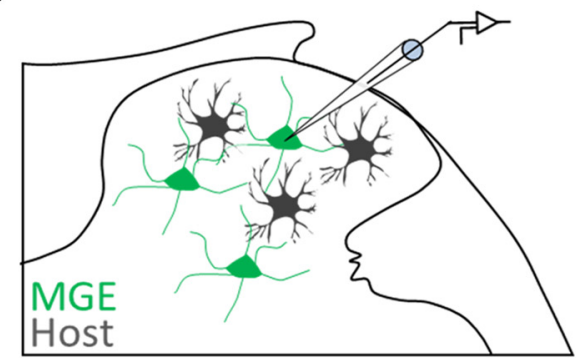

Single

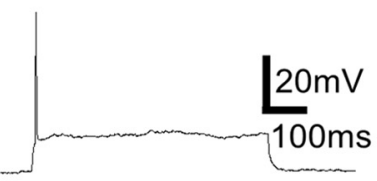

Irregular
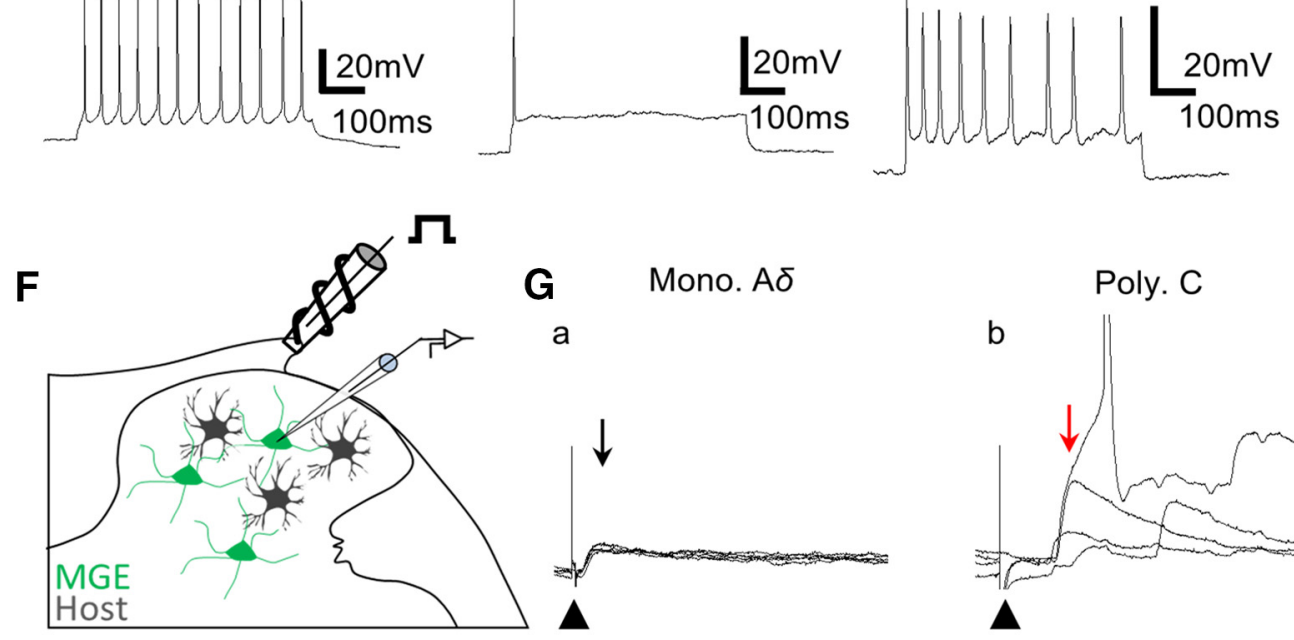

G Mono. $\mathrm{A} \delta$

a

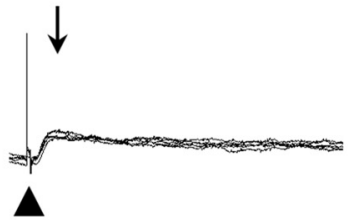

Poly. C

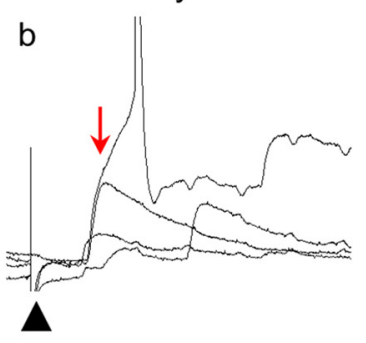

C

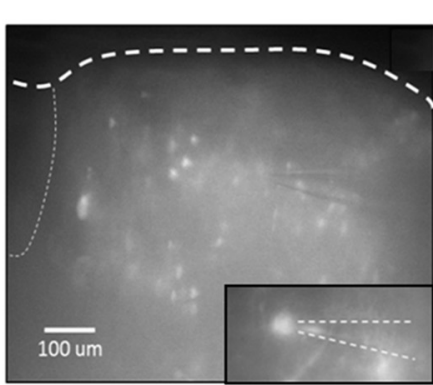

E

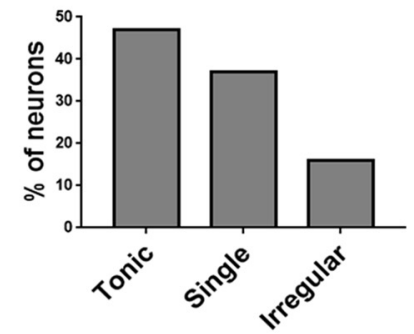

Pattern
H

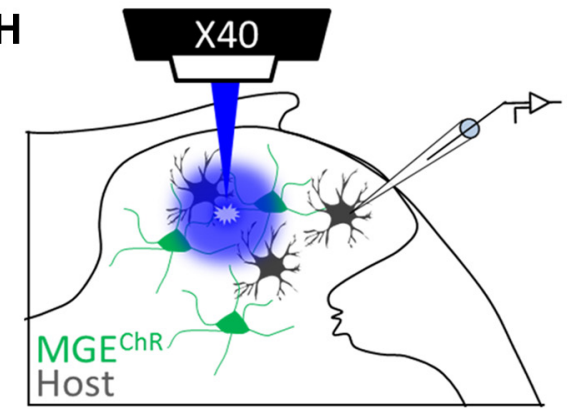

I

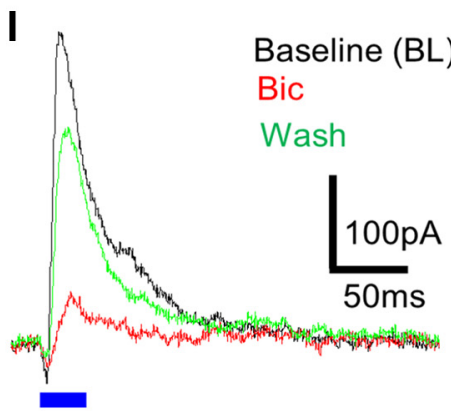

Mono. $A \delta+$ Poly. $C$

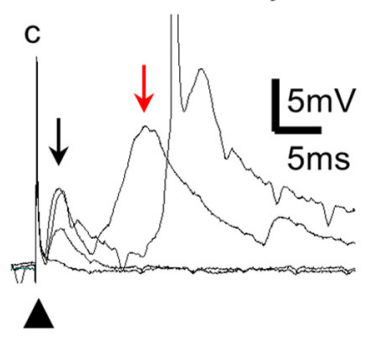

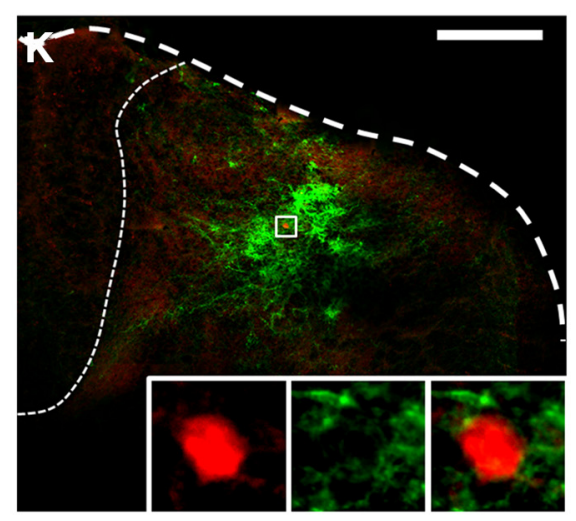

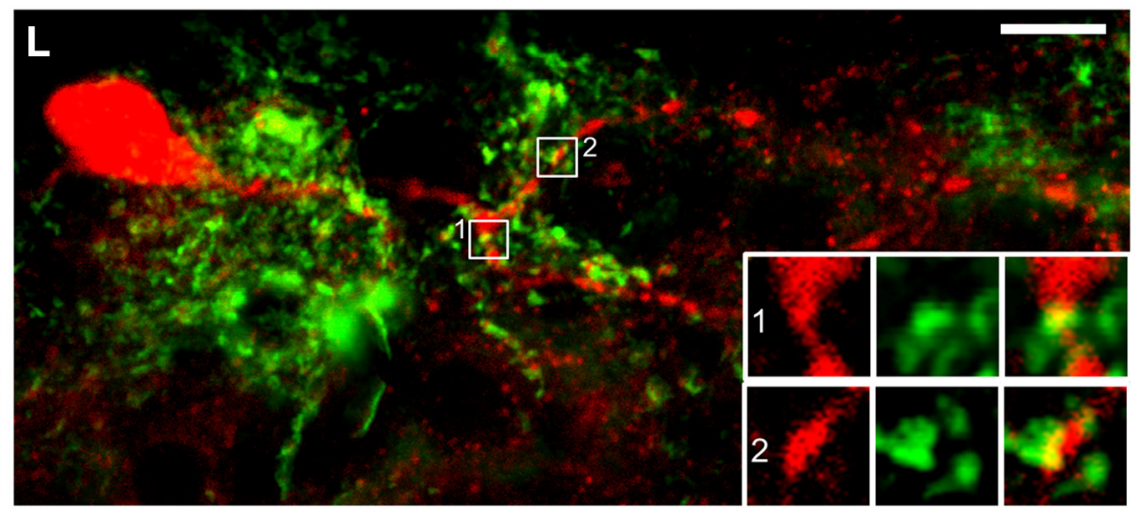

Figure 1. Functional circuit integration of MGE cells transplanted post-SNI. $A$, Mechanical thresholds recorded before and $3 \mathrm{~d}$ after nerve injury (post-SNI) and 2 and 3 weeks after MGE cell transplant ( $n=10$ mice). After the last thresholds were obtained, slice recordings (Rec) were initiated. $\boldsymbol{B}$, Schematic of the dorsal horn illustrating the setup for slice (Figure legend continues.) 

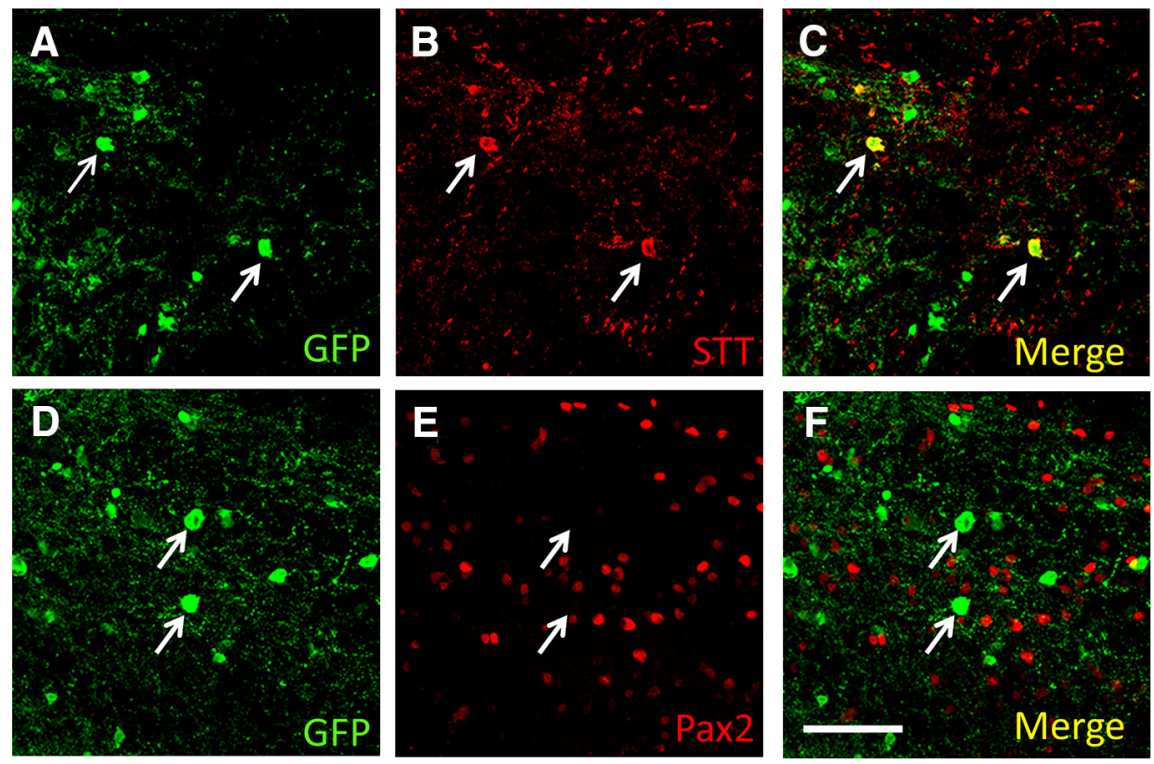

Figure 2. Post-SNI transplants express SST but not Pax2. Confocal micrographs of coronal sections prepared from lumbar segments of post-SNI mice showing double immunostaining for MGE-derived GFP and SST, a marker of subsets of cortical inhibitory interneurons ( $\boldsymbol{A}-\boldsymbol{C}$ ) and of Pax2, a marker of spinal cord inhibitory interneurons ( $\boldsymbol{D}-\boldsymbol{F})$. Approximately $40 \%$ of MGE cells expressed SST; none expressed Pax2. Scale bar, $100 \mu \mathrm{m}$.

( $n=6$ cells). Compared with bicuculline, the effect of the selective GABA-B antagonist CGP55845 $(2.0 \mu \mathrm{M})$ was less consistent. In 3 cells, the IPSCs were reduced by $20-95 \%$ and, in 3 other cells, the IPSCs actually increased by $25-60 \%$.

To verify the specific targeting of the biocytin-filled host neurons and to examine putative synaptic connections between the MGE cells and the host neurons, at the completion of the experiments, we fixed the slices and double stained them with Alexa Fluor 594conjugated SA to identify the biocytin and with anti-GFP to identify the transplanted cells. Figure $1, K$ and $L$, shows confocal micrographs

(Figure legend continued.) recording from MGE cells (green). C, Fluorescence image showing widespread distribution of GFP-expressing MGE cells in the dorsal horn. Inset is a magnified image of the recording electrode in whole-cell configuration. $\boldsymbol{D}, \boldsymbol{E}$, Current pulses most commonly evoked tonic or single/initial bursting firing patterns in post-SNI MGE cells. $F$, Schematic illustrating the setup used to examine primary afferent input to MGE cells (green) evoked by electrical stimulation of an attached dorsal root. G, Dorsal-root-evoked responses in post-SNI MGE cells. Black and red arrows indicate monosynaptic $A \delta$-fiber and polysynaptic $C$-fiber components, respectively. Ga, 5 pulses, $50 \mu \mathrm{A}, 1 \mathrm{~Hz} ; \mathbf{G b}, 4$ pulses, $500 \mu \mathrm{A}, 0.03 \mathrm{~Hz} ; \mathrm{Gc}, 4$ pulses, 500 $\mu \mathrm{A}, 0.1 \mathrm{~Hz}$. Arrowhead indicates stimulus artifact. $\boldsymbol{H}$, Experimental setup used to study the output of post-SNI MGE cells. The schematic illustrates post-SNI MGE/ChR2 ${ }^{+} / \mathrm{GFP}^{+}$cells (green) and host neurons (black) from which recordings were made. I, Optogenetically evoked IPSCs recorded in a host neuron after stimulation of MGE/ChR2 ${ }^{+} / \mathrm{GFP}^{+}$cells (30 ms light pulse, $0.5 \mathrm{~Hz}$; blue line) at BL, after 5 min incubation in bicuculline (Bic, $20 \mu \mathrm{M}$ ), and after a subsequent $20 \mathrm{~min}$ wash (Wash). The IPSC is abolished by bicuculline and almost completely restored after wash.J, Current densities of the optogenetically evoked IPSCs expressed as area under the curve (AUC) normalized first to each cell's capacitance $\left(C_{m}\right)$ and then to each cell's elPSC at BL. Bicuculline significantly reduced the optogenetically evoked IPSCS, which partially recovered after wash ( $n=8$ cells). $\boldsymbol{K}$, Confocal micrograph of a coronal spinal cord section containing a biocytin-filled (red) host neuron from which optogenetically evoked IPS(s were recorded. GFPlabeled MGE cell processes (green) surround the hostneuron. Insets show high-power images of the red, green, and merged channels corresponding to the area outlined by a white rectangle and demonstrate that the recorded host cell body and MGE cell processes are distinct. L, Confocal micrograph of a different biocytin-filled host neuron (red) from which optogenetically evoked IPSCs were recorded. Insets show high-power images of the red, green, and merged channels corresponding to the areas outlined by white rectangles ( 1 and 2 ) and demonstrate close apposition of red and green profiles (yellow), suggesting synaptic contacts between the MGE cells and the host. Scale bars: $\boldsymbol{K}, 100 \mu \mathrm{m} ; \boldsymbol{K}$ insets, $20 \mu \mathrm{m} ; \boldsymbol{L}, 10 \mu \mathrm{m} ; \boldsymbol{L}$ insets, $4.0 \mu \mathrm{m}$. of double-stained spinal cord slices and demonstrates that the recorded cells lack GFP (Fig. $1 K$ ) and that the SA-marked processes are in close apposition with MGE-derived, GFP-positive arborizations (Fig. $1 L$ ). Together, these findings demonstrate that MGE cells transplanted after SNI form functional GABAergic, predominantly bicuculline-sensitive synapses on host dorsal horn neurons.

\section{Post-SNI MGE cells transplanted into the spinal cord retain their cortical neurochemical identity}

To determine the extent to which cortically derived MGE cells that integrate extensively into the spinal cord retain their cortical identity, in these experiments, we examined the expression of known molecular markers of cortical and spinal inhibitory interneurons. Many cortical inhibitory interneurons express the peptide hormone somatostatin (SST) (Tamamaki et al., 2003; Yasaka et al., 2010; Bráz et al., 2012; Vogt et al., 2014), but in the dorsal horn, SST is found almost exclusively in excitatory interneurons (Proudlock et al., 1993; Yasaka et al., 2010; GutierrezMecinas et al., 2014). Conversely, all dorsal horn spinal cord inhibitory interneurons express the transcription factor Pax2, which is completely absent from forebrain interneurons. Here, we performed double immunostaining for MGE-derived GFP and for SST or Pax2 (Fig. 2) in spinal cord cryosections collected from post-SNI transplanted mice. Consistent with our previous report that $\sim 40 \%$ of MGE cells immunostained for SST (Bráz et al., 2012), we observed significant numbers of SST-GFP-positive, double-labeled cells (Figs. 2A-C); however, none of the MGE cells coexpressed Pax2 (Figs. 2D-F). We conclude that post-SNI MGE cells retain neurochemical features of cortical inhibitory interneurons.

\section{Behavioral consequence of MGE cell transplantation into the intact spinal cord}

Although MGE cell transplants reliably counteract peripheral nerve-injury-induced mechanical hypersensitivity, we never recorded thresholds above preinjury $\mathrm{BL}$ after transplantation. In other words, the transplants did not produce an analgesic response. The same was true for both mechanical and thermal (heat) pain thresholds in paclitaxel-treated mice that were transplanted in the lumbar spinal cord. In addition, as we reported previously, MGE cells did not alter BL mechanical pain thresholds when transplanted into the uninjured cord and were not effective in a subsequent inflammatory pain model produced by hindpaw injection of formalin (Bráz et al., 2012). We did not, however, assess the influence of an MGE cell transplant performed before SNI.

To address this question, we recorded BL mechanical thresholds of the hindpaw before and 4 weeks after unilateral MGE cell or medium transplantation into the lumbar spinal cord (Fig. 3A). Next, we induced the SNI model and retested mechanical sensitivity 1 and 2 weeks later (Fig. 3A). As expected, BL mechanical thresholds in the transplanted animals did not differ from the BL thresholds recorded before trans- 
A

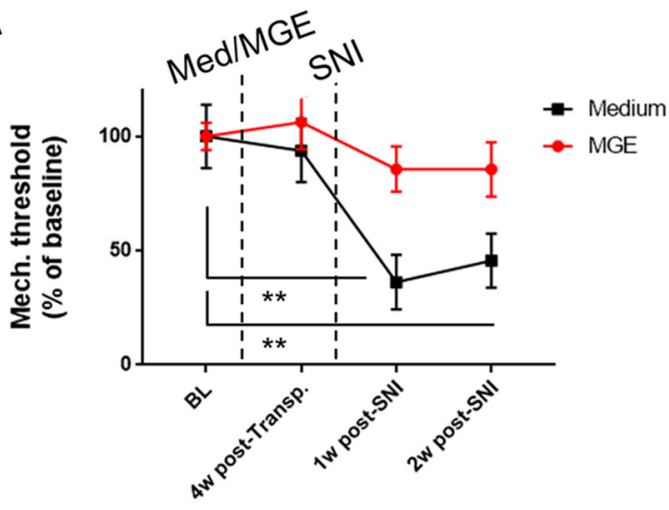

B

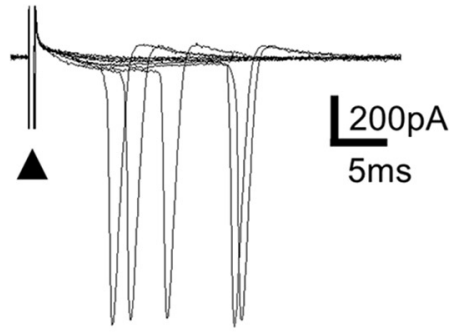

C

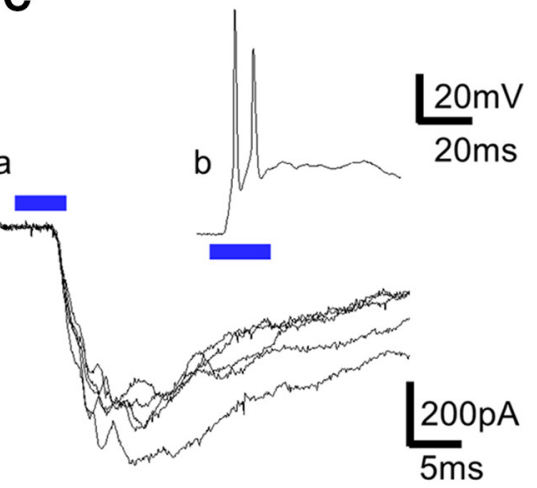

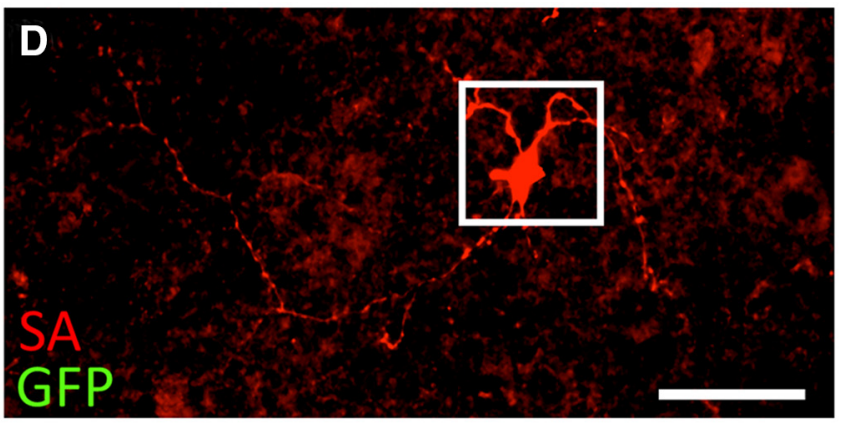
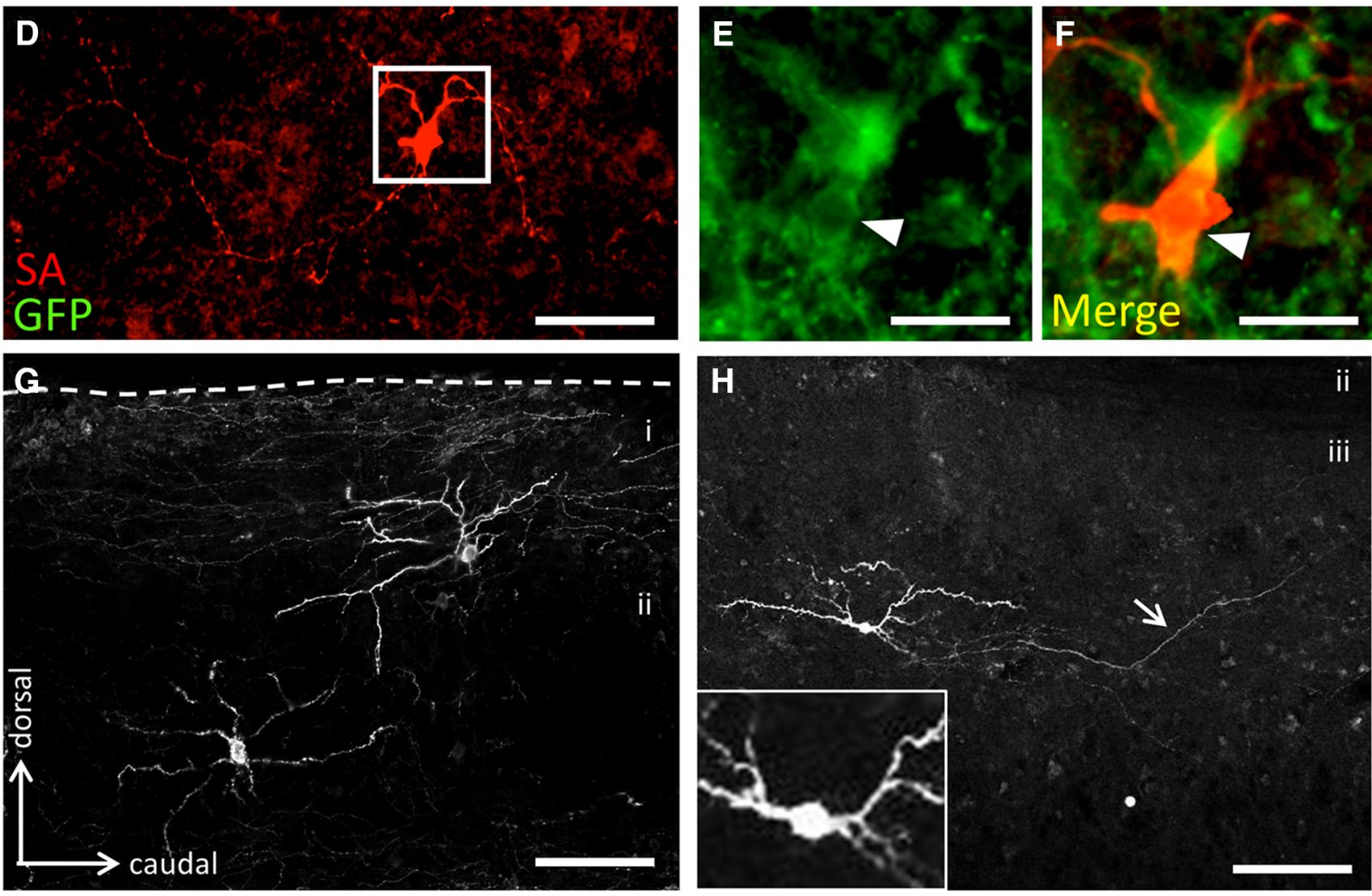

Figure 3. Functional integration of pre-SNI MGE cells prevents nerve-injury-induced mechanical hypersensitivity. $A$, Mechanical thresholds 4 weeks after transplantation of MGE cells (red) or medium (black) do not differ from BL. In the medium-injected control animals, SNI significantly reduced mechanical thresholds at both 1 and 2 weeks; however, thresholds did not differ from BL in the pre-SNI MGE transplanted animals. B, Voltage-clamp recordings illustrating dorsal root electrically evoked EPSCs in a pre-SNI MGE cell (10 pulses, $1 \mathrm{~mA}, 0.1 \mathrm{~Hz}$; 10 superimposed traces). Arrowhead indicates stimulus artifact. The presence of failures and relatively long and inconsistent latency of the responses suggest a polysynaptic connection. $\boldsymbol{C}$, EPSCs (Ca, 5 traces) and APs ( $\boldsymbol{C b}, A P$ s; single trace) evoked in a pre-SNI MGE cell after optogenetic stimulation of TRPV1 primary afferent terminals that express ChR2 (blue line; $460 \mathrm{~nm}$, 5 and $20 \mathrm{~ms}$ pulse duration for EPSPs and APs, respectively). $\boldsymbol{D}-\boldsymbol{F}$, Confocal micrographs of a recorded, biocytin-filled multipolar MGE cell located in lamina V visualized with SA (red) and immunostained for GFP (green; $\boldsymbol{E}$ ). Arrowheads in $\boldsymbol{E}$ and $\boldsymbol{F}$ point to the GFP-SA colabeled cell body. $\boldsymbol{G}, \boldsymbol{H}$, Confocal micrographs (Z-stack projection) of a sagittal section of the lumbar spinal cord showing representative examples of GFP-expressing pre-SNI MGE cells and their dendritic and axonal arbors 3 weeks after transplantation. Dotted line defines dorsal edge of the cord; $\boldsymbol{i}$-iii denote superficial dorsal horn laminae. Inset in $\boldsymbol{H}$ illustrates characteristic round morphology of this transplanted cell. The arrow points to the extensive rostrocaudal axonal arborizations. Scale bars: $\boldsymbol{D}, 100 \mu \mathrm{m} ; \boldsymbol{E}, \boldsymbol{F}, 30 \mu \mathrm{m} ; \boldsymbol{G}, 80 \mu \mathrm{m} ; \boldsymbol{H}, 130 \mu \mathrm{m} ; \boldsymbol{H}$ inset, $40 \mu \mathrm{m}$.

plantation. The same was true for control mice that only received an injection of the transplant medium (BL vs 4 weeks after transplant, 2-way ANOVA, $F_{(3,72)}=6.73$, followed by Tukey's post hoc test; $p>0.05$ ). To our surprise, however, whereas medium-transplanted SNI mice developed the expected mechanical allodynia (2-way ANOVA, $F_{(3,72)}=1.98$, Tukey post hoc test, BL vs 1 week post-SNI $p<0.01$; BL vs 2 weeks post-SNI, $p<0.01$ ), the mechanical thresholds of ani- mals that received MGE cells never differed from BL (Fig. 3A, $\mathrm{BL}$ vs 1 week and 2 weeks post-SNI, 2-way ANOVA, $F_{(3,72)}=$ 6.73 , followed by Tukey's post hoc test; $p>0.05$ for the MGE cohort). Therefore, in contrast to nocifensive behaviors in the formalin model, which are not influenced by prior MGE cell transplantation, these transplants prevent development of the mechanical hypersensitivity that is normally produced in this neuropathic pain model. 


\section{Pre-SNI MGE cells exhibit intrinsic properties characteristic of GABAergic interneurons}

Having established a profound, prophylactic effect of transplants performed in naive animals (i.e., before nerve injury), we next addressed the nature and extent of the integration of the transplants into the uninjured cord. Here, we used the same paradigm as in the post-SNI experiments (Fig. 1B). In transverse spinal cord slices, we obtained recordings from 34 MGE cells in 18 naive mice. The cells were located throughout the dorsal horn. The level of spontaneous activity was examined in 16 of these cells. Thirteen $(81 \%)$ of these cells exhibited spontaneous firing (46.34 $\pm 17 \mathrm{APs} / \mathrm{min})$ and all (16/16) had various levels of spontaneous EPSPs ( $41 \pm 9.4$ events/10 s). Neither spontaneous firing nor the number of spontaneous EPSPs differed between the postSNI and pre-SNI MGE cells (Mann-Whitney test, $p=0.46$ ). Introducing incremental depolarizing current steps revealed that 27 of the total $34 \mathrm{MGE}$ cells (79\%) exhibited a tonic firing pattern, 5/34 (15\%) exhibited a "single" or "initial bursting" pattern, and only $2 / 34$ (6\%) exhibited the "irregular" pattern. We conclude that immature MGE cells transplanted into the naive adult spinal cord also develop into functional neurons and exhibit activity patterns predominantly characteristic of inhibitory interneurons.

Table 1 summarizes the intrinsic properties of the pre-SNI and post-SNI MGE cells. Many of the properties did not differ between the two groups; however, some significant differences were observed. First, the mean membrane potential of the postSNI MGE cells was significantly more depolarized compared with the pre-SNI MGE cells $(-55.52 \pm 1.89 \mathrm{mV}$ vs $-63.56 \pm 1.7 \mathrm{mV}$, Mann-Whitney test, $p=0.0049)$. Second, the mean amplitude of APs of the post-SNI MGE cells was significantly smaller than that of the pre-SNI MGE cells $(43.73 \pm 4.47 \mathrm{mV}$ vs $60.6 \pm 3.1 \mathrm{mV}$, Mann-Whitney test, $p=0.0048)$. Finally, the mean AP halfwidth was significantly larger in post-SNI than in pre-SNI MGE cells $(2.55 \pm 0.41 \mathrm{~ms}$ vs $1.7 \pm 0.2 \mathrm{~ms}$, Mann-Whitney test, $p=$ $0.021)$. Although firing frequency tended to be higher in pre-SNI MGE cells compared with post-SNI MGE cells, the difference was not statistically significant.

\section{Nociceptive primary afferent fibers activate pre-SNI transplanted MGE cells}

Similar to the post-SNI studies, here we investigated whether primary afferents can activate pre-SNI MGE cells. We first used electrical stimulation of primary afferents in a paradigm identical to that used in our analysis of post-SNI cells (Fig. $1 F$ ). We obtained recordings of responses evoked by dorsal root stimulation ( $1 \mathrm{~Hz}, 1.0 \mathrm{~ms}$ pulse duration) from $4 \mathrm{MGE}$ cells (Fig. $3 B ; n=4$ mice). Using the same criteria as for the post-SNI MGE cells, we determined that two of four cells received a monosynaptic input (Pinco and Lev-Tov, 1993; Yoshimura and Nishi, 1993). In a third cell, we observed considerable jitter and, in another cell, we recorded occasional failures, which suggests that the latter two cells received a polysynaptic input from the afferents. In contrast to a previous report, we never observed inhibitory input to dorsal horn interneurons (Yoshimura and Nishi, 1995).

Next, to determine whether MGE cells respond to selective activation of nociceptive afferents, we transplanted embryonic MGE cells from wild-type mice into mice that Cre-dependently express ChR2 under the control of the TRPV1 promoter (see Materials and Methods). Because TRPV1 is transiently expressed during development in a mixed population of unmyelinated fibers, in these double-transgenic TRPV1-Cre $\times$ floxed-ChR2 mice, the ChR2 is expressed in both peptidergic and nonpepti- dergic unmyelinated afferents (Cavanaugh et al., 2011). We obtained recordings from seven MGE cells in four different TRPV1-ChR2 mice. In 5 of the 7 cells, we recorded EPSCs after blue light stimulation of the TRPV $1^{+} / \mathrm{ChR} 2^{+}$terminals (a train of 5 light pulses, $0.2-10 \mathrm{~s}$ interstimulus interval; Fig. $3 \mathrm{Ca}$ ). The mean latency of these EPSCs was 7.6 $\pm 1.2 \mathrm{~ms}$ and the mean peak amplitude was $-223.7 \pm 134 \mathrm{pA}$. In four of five responding cells, optogenetic stimulation of the TRPV $1{ }^{+} / \mathrm{ChR} 2{ }^{+}$terminals evoked APs (Fig. 3Cb). Control stimulation with green light had no effect on the host neurons (data not shown). As with electrical stimulation, we never found IPSCs in the recorded MGE cells in response to stimulation of $\mathrm{TRPV} 1{ }^{+} / \mathrm{ChR} 2{ }^{+}$terminals. Despite the limited sample of responding cells in these experiments, together with the post-SNI findings described above, these results indicate that sensory neurons, including some that are nociceptive, likely activate transplanted MGE cells, regardless of whether the transplants were made before or after a peripheral nerve injury.

\section{Morphology of the transplanted MGE cells}

To verify the targeting and to study the morphology of the preSNI MGE neurons, after completion of the electrophysiological experiments, we double immunostained the slices with an antiGFP antibody to identify the transplanted neurons and with SA to visualize the biocytin-filled recorded neurons. We reconstructed the dendritic arbors of four MGE cells that were transplanted before injury (Fig. 3D-H). These cells had round, multipolar cell bodies, with dendritic trees that crossed laminar borders, features much more characteristic of cortical GABAergic than spinal cord GABAergic interneurons (Grudt and Perl, 2002; Yasaka et al., 2010). The axons of two of these neurons could be followed for several hundred micrometers from the cell body (Fig. $3 \mathrm{D}, \mathrm{H}$ ) toward the superficial dorsal horn laminae. Unfortunately, we were not successful in reconstructing the morphology of postSNI MGE cells because we could not break the seal and retract the recording pipette at the end of the experiment without damaging the cell.

\section{Pre-SNI transplanted MGE cells form functional GABAergic synapses on host neurons}

Having demonstrated that transplantation of MGE cells before injury can prevent subsequent development of mechanical hypersensitivity, thus demonstrating functional relevance of MGE cell integration into the naive spinal cord, we next investigated whether this integration involves GABAergic connections between the MGE cells and host neurons. As in the post-SNI studies, we recorded responses from host neurons of the superficial dorsal horn in slices of spinal cord from naive mice previously transplanted with MGE cells that express ChR2 under control of the ROSA26 promoter (see Materials and Methods; Fig. $1 H$ ). With membrane potential of the recorded neurons clamped at $+10 \mathrm{mV}$, we found that optogenetic stimulation of the transplanted neurons evoked IPSCs in 9 of 26 (34\%) randomly identified host neurons ( $n=7$ mice; Fig. $4 A, B L)$. Six of the responding host neurons were located in lamina II and three in deeper laminae. In 7/9 (78\%) responding cells, bicuculline $(20 \mu \mathrm{M})$ significantly reduced the optogenetically evoked IPSCs (percentage reduction: $73 \pm 0.08 \%$ of the BL levels; Friedman test, Friedman statistic $=8.857$, groups $=3$, subjects $=7$, followed by Dunn's post hoc test, $p=0.01$ ) and these recovered to $76.9 \pm 26.3 \%$ of the BL level after washout (Fig. 4A,B, Bic, Wash).

At the completion of these experiments, we fixed and double labeled the slices for MGE-derived GFP and for biocytin. Figure 
A

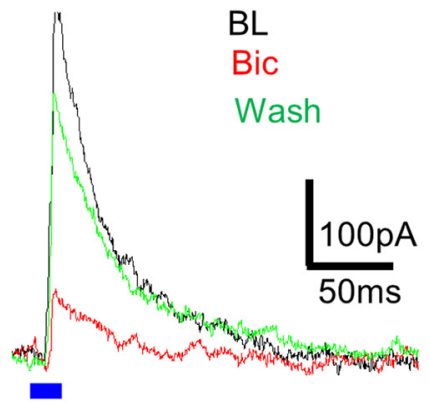

B

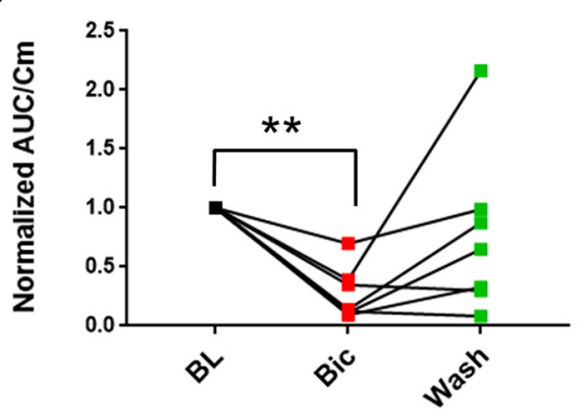

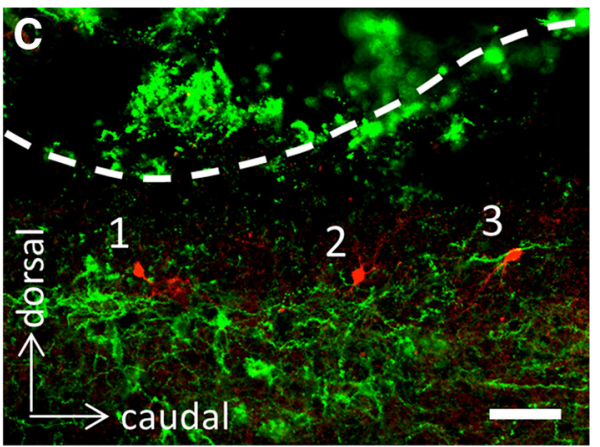
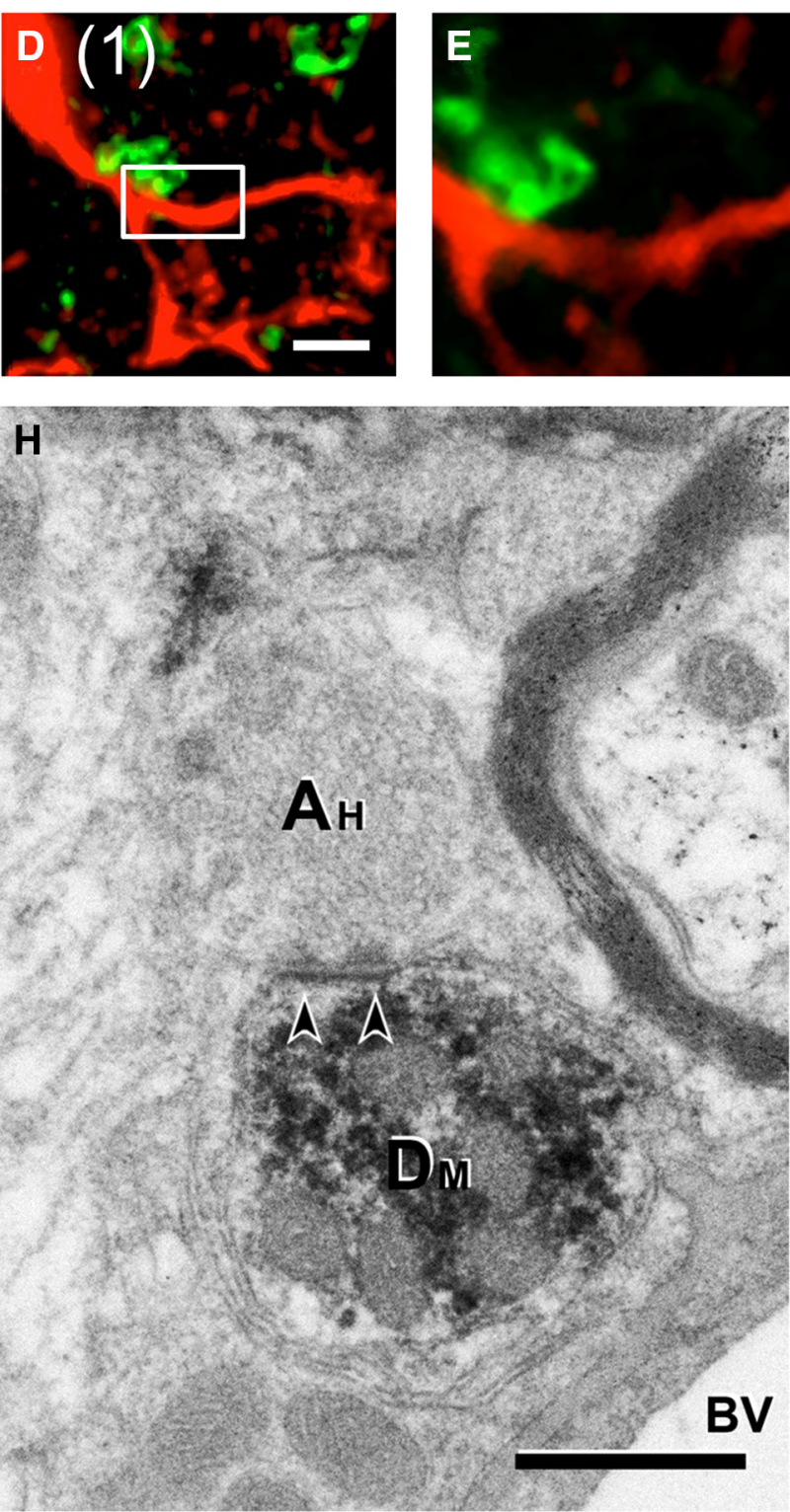
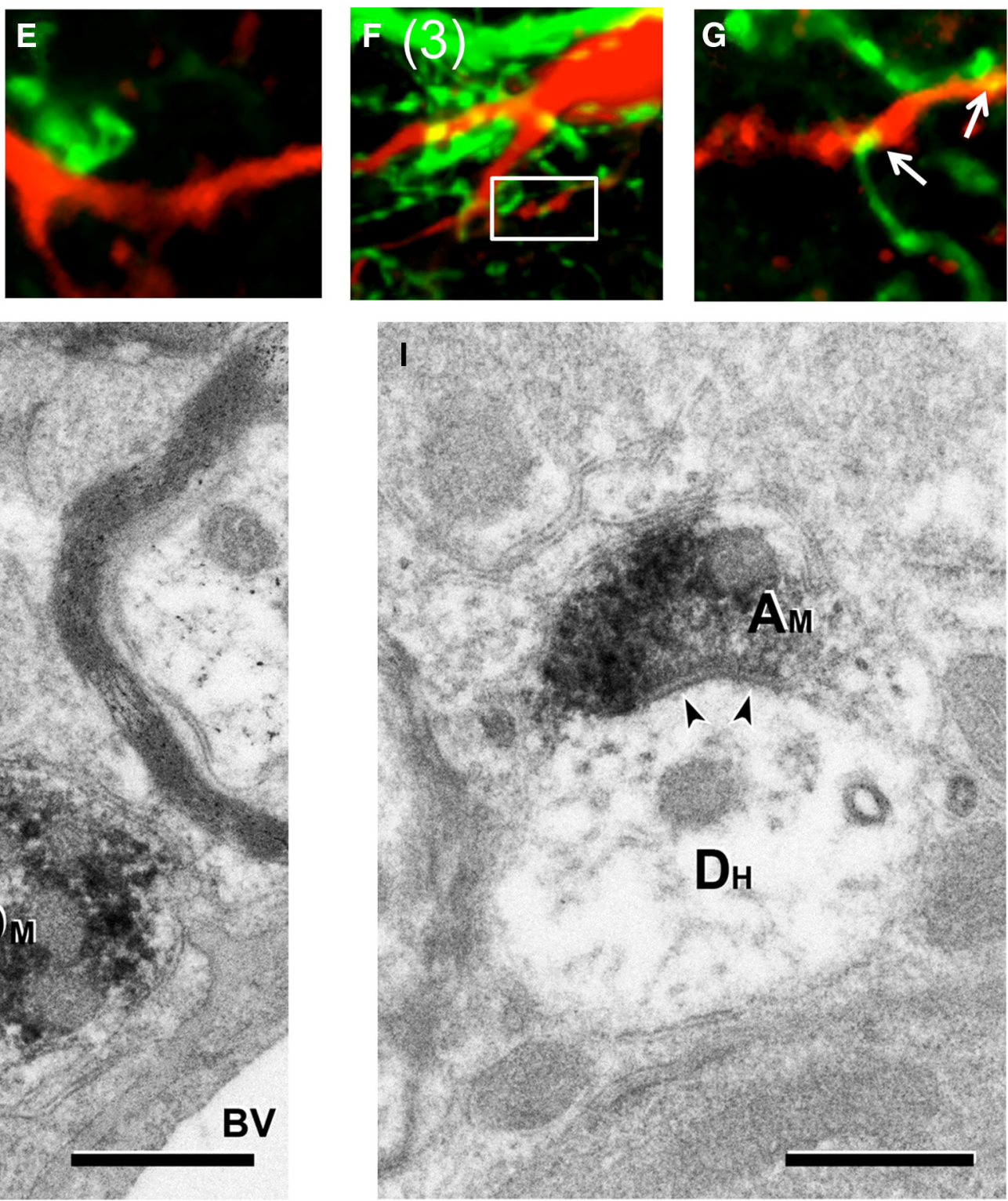

Figure 4. Pre-SNI MGE cells form functional GABAergic synaptic connections with host neurons. $A$, Optogenetically evoked IPSCs recorded from a host neuron after stimulation of MGE/ChR2 ${ }^{+} /$ $\mathrm{GFP}^{+}$cells (20 ms light pulse, $460 \mathrm{~nm}$, blue line) before (BL), after 16 min incubation in bicuculline (20 $\left.\mu \mathrm{m}, \mathrm{Bic}\right)$, and after a subsequent 20 min wash (Wash). The IPSC is abolished by bicuculline and restored after wash. $\boldsymbol{B}$, Current densities of the optogenetically evoked IPSCs expressed as area under the curve (AUC) normalized first to each cell's capacitance $\left(C_{m}\right)$ and then to each cell's elPSC at BL. Bicuculline reduced the optogenetically evoked IPSCs that recovered after wash $(n=7$ cells). C, Two-photon micrograph of a sagittal section of the dorsal horn containing three biocytin-filled host cells (red) in the vicinity of several transplanted MGE/ChR2 ${ }^{+} / \mathrm{GFP}^{+}$cells and processes (green). The dashed line marks the dorsal edge of the spinal cord. Only host cell \#3 responded to optogenetic stimulation of the MGE cells. D-G,Z-stack projection of host cells \#1 (D) and \#3 (F). In contrast to the unresponsive host neuron (\#1), the responsive neuron (\#3) is contacted by a plethora of GFP ${ }^{+}$processes. $E, G$, High-power images of the area outlined by white rectangles in $\boldsymbol{D}$ and $\boldsymbol{F}$, respectively. Arrows indicate close apposition of GFP ${ }^{+}$and host processes. $\boldsymbol{H}, \boldsymbol{I}$, Electron micrographs of lumbar dorsal horn prepared from naive mice (Pre-SNI) 3 weeks after transplantation of MGE cells. H, GFP-immunoperoxidase labeled MGE cell transplant-derived dendrite (DM) postsynaptic to a GFP-negative host axon terminal (AH). I, GFP-immunperoxidase-labeled MGE transplant-derived axon (AM) presynaptic to a GFP-negative host dendrite (DH). Arrowheads indicate synaptic densities. BV, Blood vessel. Scale bars: $C, 50 \mu \mathrm{m} ; \boldsymbol{D}, \boldsymbol{F}, 5 \mu \mathrm{m} ; \boldsymbol{H}, \boldsymbol{I}, 0.5 \mu \mathrm{m}$. 
$4 C$ is a low-power two-photon micrograph from a parasagittal section that contains three biocytin-filled host cells (red). The section also contains many MGE cells and processes (green). Cell \#3 responded to light stimulation of the MGE cells; cells \#1 and \#2 did not respond. Putative contacts between GFP-expressing neurites of the MGE cells and the biocytin-filled host cells are illustrated in the accompanying high-magnification confocal micrographs (Figs. $4 E, G$ ). Finally, in preliminary electron microscopic studies, we confirmed that the contacts indeed represent bona fide synaptic interactions between the transplanted neurons and the host (Figs. 4H,I). Together, these findings demonstrate that MGE cells transplanted before SNI not only receive synaptic inputs from the host, but also form functional GABAergic, bicuculline-sensitive synapses on host dorsal horn neurons.

\section{Discussion}

Here, we examined the extent to which transplanted MGE cells integrate synaptically into the neural circuitry of the host spinal cord. Using electrophysiology, immunohistochemistry, and electron microcopy, we provide evidence that the transplanted cells indeed form synaptic connections with the host regardless of whether the transplants were performed after nerve injury or in naive mice. With the exception of some minor differences in membrane properties, the pre-SNI and post-SNI transplanted MGE cells exhibited similar physiological and morphological properties. In both conditions, the MGE cells developed into mature neurons, exhibited intrinsic firing patterns comparable to those reported for subpopulations of CNS inhibitory interneurons, and could be activated monosynaptically and polysynaptically by lowand high-threshold primary afferents. Furthermore, optogenetic activation of the transplanted cells exerted a bicuculline-sensitive (i.e., GABA-A mediated), inhibitory action on host neurons. Most unexpectedly, we found that MGE cells transplanted into naive spinal cord could prevent the development of mechanical hypersensitivity in a subsequent SNI model of neuropathic pain.

\section{Morphological and neurochemical properties of transplanted MGE cells}

Endogenous cortical GABAergic interneurons (Miyoshi et al., 2010) and MGE cells transplanted into the adult cortex (Vogt et al., 2014) exhibit a comparable morphology. Both populations of neurons have a round cell body with dendrites that arborize extensively. The same morphology characterizes MGE cells transplanted into the spinal cord regardless of whether the transplant occurred before or after SNI. Because this morphology differs considerably from the typical, "islet cell" GABAergic dorsal horn interneuron, which has a fusiform cell body with dendrites and axons that arborize almost exclusively in the rostrocaudal direction, we conclude that the transplanted neurons retain significant cortical properties (Grudt and Perl, 2002; Heinke et al., 2004; Yasaka et al., 2010; but see Iwagaki et al., 2016). Consistent with this conclusion, we found that the transplanted cells also have a cortical neurochemistry. Specifically, many of the transplanted cells express somatostatin and none express Pax2, which are molecular markers that define subtypes of cortical and spinal cord GABAergic interneuron, respectively.

\section{Electrophysiological properties of transplanted MGE cells}

Previous studies found that subpopulations of cortical and spinal cord inhibitory interneurons, as well as MGE cells transplanted into the cortex, manifest a range of membrane property values (Heinke et al., 2004; Schoffnegger et al., 2006; Miyoshi et al., 2010; Yasaka et al., 2010; Vogt et al., 2014). In the present study, both pre-SNI and post-SNI MGE cells exhibited intrinsic membrane properties that fall well within this range; however, the values were not identical in the two groups. For example, we found differences in mean resting membrane potential, AP amplitude, and threshold for AP generation (the latter not statistically significant) between pre-SNI and post-SNI MGE cells. These findings suggest that post-SNI transplantation rendered the MGE cells less excitable, but the functional relevance of these findings is unclear.

Several studies used firing patterns in response to a depolarizing current step to characterize subpopulations of CNS inhibitory interneurons (Grudt and Perl, 2002; Miyoshi et al., 2010). Most of these inhibitory neurons fire tonically with minimal adaptation; another group responds with a single/initial burst of APs and adapts rapidly. The same patterns predominate in MGE cells transplanted into the cortex. Here, we found comparable patterns in MGE cells transplanted into the spinal cord either before or after SNI, with some difference in the percentage of transplanted neurons exhibiting one or the other pattern. Based on morphology, neurochemistry, and electrophysiological properties, therefore, we conclude that MGE cells transplanted into the spinal cord develop into functional inhibitory interneurons that retain their cortical phenotype and that it is the release of GABA that is critical to the inhibition of host neurons and to the ability of the transplants to overcome the mechanical hypersensitivity in several different neuropathic pain models (Basbaum and Bráz, 2016). We realize that some dorsal horn inhibitory interneurons coexpress GABA and glycine (Proudlock et al., 1993 ) and that loss of glycinergic controls has been implicated in the development of neuropathic pain (Miraucourt et al., 2007; Foster et al., 2015); however, given the uncertainty as to the glycinergic content of MGE cells, together with our findings demonstrating blockade of optogenetically evoked MGE-derived IPSCs by the GABA-A antagonist bicuculline, the bulk of the evidence points to a predominant contribution of GABAergic inhibitory control deriving from the transplants.

\section{Synaptic interactions underlying MGE-cell-mediated inhibitory control}

In our first analysis of the integration of MGE cells into host circuits, we demonstrated transneuronal transfer of genetically expressed wheat germ agglutinin from the host to MGE cells, as well as from the transplanted cells to the host. Those findings were consistent with, but could not establish, synaptic connectivity. Here, using confocal and electron microscopic analysis, we provide direct anatomical evidence that the transplanted neurons establish synaptic connections with the host. Most importantly, we also determined the pharmacological nature of these synapses. The GABA-A antagonist bicuculline blocked optogenetically evoked MGE-derived IPSCs in host neurons. In contrast, the GABA-B receptor antagonist CGP55845 produced equivocal results. Together with our previous demonstration that transplants of MGE cells from VGAT mutant mice survived, but did not overcome, nerve-injury-induced mechanical hypersensitivity (Bráz et al., 2015), we conclude that GABA is not only required for reestablishing inhibitory control, but also that the control is predominantly GABA-A receptor mediated.

We also demonstrate functional synaptic connections between nociceptive afferents and the transplanted neurons. Specifically, we found that MGE cells are both monosynaptically and polysynaptically activated by high-threshold $\mathrm{A} \delta$ - and C-fibers, in particular by the TRPV1 subset of nociceptors. These findings extend our earlier report that used Fos induction and transneu- 
ronal tracing to demonstrate that MGE cells can be activated by both noxious and innocuous afferent stimulation and that myelinated and unmyelinated afferents engage the transplanted neurons (Bráz et al., 2012). Because endogenous dorsal horn GABAergic interneurons receive comparable inputs (Schoffnegger et al., 2006; Daniele and MacDermott, 2009; Leitner et al., 2013), we conclude that the afferent drive to the transplanted cells recapitulates many features of host inhibitory circuits.

\section{Prophylactic effect of transplanted neurons}

Completely unexpected was our finding that MGE cell transplantation before nerve injury can prevent the development of the mechanical hypersensitivity. An important clue to the basis of this profound prophylactic action comes from our previous finding that MGE cells transplanted after nerve injury normalized mechanical thresholds that were reduced by the injury, but did not have an analgesic effect. In other words, thresholds did not exceed BL, preinjury levels. The transplants also normalized dorsal horn GAD mRNA levels (Bráz et al., 2012), which are significantly reduced after injury (Moore et al., 2002). Because previous studies reported that MGE cells express both the GAD65 and GAD67 isoforms (Tricoire et al., 2011), it is not clear whether one or the other predominates in the pain-relieving effects of the transplant. Importantly, transplanting MGE cells into naive animals also had no effect on BL thresholds (Fig. 3A) and did not increase GAD mRNA levels above normal (Bráz et al., 2012). Preinjury transplants may therefore prevent nerve-injuryinduced mechanical hypersensitivity because the transplanted cells maintain a level of inhibition that is typically lost after nerve injury. Importantly, the lack of effect of MGE cells in the absence of nerve injury cannot be attributed to a lack of spontaneous activity because we found that $>80 \%$ of MGE cells exhibited spontaneous firing in both pre-SNI and post-SNI conditions.

Interestingly, MGE cells are not effective against all pain conditions when transplanted before an insult. As noted above, nocifensive behaviors in the first hour after hindpaw injection of formalin are not altered by prior transplantation of MGE cells (Bráz et al., 2012). Therefore, the MGE transplants are not generally prophylactic, but may only be effective in models of nerveinjury-induced neuropathic pain. These observations contrast completely with the readily demonstrated increases in BL pain thresholds produced by intrathecal administration of GABA agonists (Hammond and Drower, 1984), as well as by their profound effects in the formalin test (Dirig and Yaksh, 1995).

Consistent with our previous reports, we demonstrated that MGE cells arborize extensively in all directions and are thus positioned to form connections with a large number of spinal cord neurons. Based on these observations, we conclude that the transplants do not merely act as a sophisticated cellular pump that releases GABA throughout the dorsal horn, effectively mimicking an intrathecal injection. Rather, it is the extensive arborization and robust synaptic integration into the host that underlies the utility of the transplants and their prophylactic effects. It is also possible that the preserved cortical phenotype and the embryonic origin of the transplanted neurons, which endows them with a high intrinsic growth capacity, renders the MGE cells less susceptible to the deleterious consequence of nerve injury (Southwell et al., 2014). In fact, the structural plasticity evidenced by both the transplants and the host is, in many respects, one of the most remarkable features of our study and underscores the potential for future cell-based CNS therapies.

\section{References}

Alvarez-Dolado M, Calcagnotto ME, Karkar KM, Southwell DG, Jones-Davis DM, Estrada RC, Rubenstein JL, Alvarez-Buylla A, Baraban SC (2006) Cortical inhibition modified by embryonic neural precursors grafted into the postnatal brain. J Neurosci 26:7380-7389. CrossRef Medline

Basbaum AI, Bráz JM (2016) Cell transplants to treat the "disease" of neuropathic pain and itch. Pain 157:S42-S47. CrossRef Medline

Basbaum AI, Bautista DM, Scherrer G, Julius D (2009) Cellular and molecular mechanisms of pain. Cell 139:267-284. CrossRef Medline

Bráz JM, Sharif-Naeini R, Vogt D, Kriegstein A, Alvarez-Buylla A, Rubenstein JL, Basbaum AI (2012) Forebrain GABAergic neuron precursors integrate into adult spinal cord and reduce injury-induced neuropathic pain. Neuron 74:663-675. CrossRef Medline

Bráz JM, Wang X, Guan Z, Rubenstein JL, Basbaum AI (2015) Transplantmediated enhancement of spinal cord GABAergic inhibition reverses paclitaxel-induced mechanical and heat hypersensitivity. Pain 156:10841091. CrossRef Medline

Cavanaugh DJ, Chesler AT, Bráz JM, Shah NM, Julius D, Basbaum AI (2011) Restriction of transient receptor potential vanilloid-1 to the peptidergic subset of primary afferent neurons follows its developmental downregulation in nonpeptidergic neurons. J Neurosci 31:10119-10127. CrossRef Medline

Chaplan SR, Bach FW, Pogrel JW, Chung JM, Yaksh TL (1994) Quantitative assessment of tactile allodynia in the rat paw. J Neurosci Methods 53:5563. CrossRef Medline

Daniele CA, MacDermott AB (2009) Low-threshold primary afferent drive onto GABAergic interneurons in the superficial dorsal horn of the mouse. J Neurosci 29:686-695. CrossRef Medline

Dirig DM, Yaksh TL (1995) Intrathecal baclofen and muscimol, but not midazolam, are antinociceptive using the rat-formalin model. J Pharmacol Exp Ther 275:219-227. Medline

Eaton MJ, Plunkett JA, Karmally S, Martinez MA, Montanez K (1998) Changes in GAD- and GABA- immunoreactivity in the spinal dorsal horn after peripheral nerve injury and promotion of recovery by lumbar transplant of immortalized serotonergic precursors. J Chem Neuroanat 16:5772. CrossRef Medline

Eaton MJ, Plunkett JA, Martinez MA, Lopez T, Karmally S, Cejas P, Whittemore SR (1999) Transplants of neuronal cells bioengineered to synthesize GABA alleviate chronic neuropathic pain. Cell Transplant 8:87-101. Medline

Ferrini F, De Koninck Y (2013) Microglia control neuronal network excitability via BDNF signalling. Neural Plast 2013:429815. CrossRef Medline

Foster E, Wildner H, Tudeau L, Haueter S, Ralvenius WT, Jegen M, Johannssen H, Hösli L, Haenraets K, Ghanem A, Conzelmann KK, Bösl M, Zeilhofer HU (2015) Targeted ablation, silencing, and activation establish glycinergic dorsal horn neurons as key components of a spinal gate for pain and itch. Neuron 85:1289-1304. CrossRef Medline

Fukuhara K, Katafuchi T, Yoshimura M (2013) Effects of baclofen on mechanical noxious and innocuous transmission in the spinal dorsal horn of the adult rat: in vivo patch-clamp analysis. Eur J Neurosci 38:3398-3407. CrossRef Medline

Fukuoka T, Tokunaga A, Kondo E, Miki K, Tachibana T, Noguchi K (1998) Change in mRNAs for neuropeptides and the GABA(A) receptor in dorsal root ganglion neurons in a rat experimental neuropathic pain model. Pain 78:13-26. CrossRef Medline

Grudt TJ, Perl ER (2002) Correlations between neuronal morphology and electrophysiological features in the rodent superficial dorsal horn. J Physiol 540:189-207. CrossRef Medline

Gutierrez-Mecinas M, Watanabe M, Todd AJ (2014) Expression of gastrinreleasing peptide by excitatory interneurons in the mouse superficial dorsal horn. Mol Pain 10:79. CrossRef Medline

Hammond DL, Drower EJ (1984) Effects of intrathecally administered THIP, baclofen and muscimol on nociceptive threshold. Eur J Pharmacol 103:121-125. CrossRef Medline

Heinke B, Ruscheweyh R, Forsthuber L, Wunderbaldinger G, Sandkühler J (2004) Physiological, neurochemical and morphological properties of a subgroup of GABAergic spinal lamina II neurones identified by expression of green fluorescent protein in mice. J Physiol 560:249-266. CrossRef Medline

Ibuki T, Hama AT, Wang XT, Pappas GD, Sagen J (1997) Loss of GABAimmunoreactivity in the spinal dorsal horn of rats with peripheral nerve 
injury and promotion of recovery by adrenal medullary grafts. Neuroscience 76:845-858. Medline

Iwagaki N, Ganley RP, Dickie AC, Polgár E, Hughes DI, Del Rio P, Revina Y, Watanabe M, Todd AJ, Riddell JS (2016) A combined electrophysiological and morphological study of neuropeptide Y-expressing inhibitory interneurons in the spinal dorsal horn of the mouse. Pain 157:598-612. CrossRef Medline

Jergova S, Hentall ID, Gajavelli S, Varghese MS, Sagen J (2012) Intraspinal transplantation of GABAergic neural progenitors attenuates neuropathic pain in rats: a pharmacologic and neurophysiological evaluation. Exp Neurol 234:39-49. CrossRef Medline

Kaneko M, Mestre C, Sánchez EH, Hammond DL (2000) Intrathecally administered gabapentin inhibits formalin-evoked nociception and the expression of Fos-like immunoreactivity in the spinal cord of the rat. J Pharmacol Exp Ther 292:743-751. Medline

Kawaguchi Y, Kubota Y (1997) GABAergic cell subtypes and their synaptic connections in rat frontal cortex. Cereb Cortex 7:476-486. CrossRef Medline

Knabl J, Witschi R, Hösl K, Reinold H, Zeilhofer UB, Ahmadi S, Brockhaus J, Sergejeva M, Hess A, Brune K, Fritschy JM, Rudolph U, Möhler H, Zeilhofer HU (2008) Reversal of pathological pain through specific spinal GABAA receptor subtypes. Nature 451:330-334. CrossRef Medline

Leitner J, Westerholz S, Heinke B, Forsthuber L, Wunderbaldinger G, Jäger T, Gruber-Schoffnegger D, Braun K, Sandkühler J (2013) Impaired excitatory drive to spinal GABAergic neurons of neuropathic mice. PLoS One 8:e73370. CrossRef Medline

Lever I, Cunningham J, Grist J, Yip PK, Malcangio M (2003) Release of BDNF and GABA in the dorsal horn of neuropathic rats. Eur J Neurosci 18:1169-1174. CrossRef Medline

Llewellyn-Smith IJ, Minson JB (1992) Complete penetration of antibodies into vibratome sections after glutaraldehyde fixation and ethanol treatment: light and electron microscopy for neuropeptides. J Histochem Cytochem 40:1741-1749. CrossRef Medline

Llewellyn-Smith IJ, Dicarlo SE, Collins HL, Keast JR (2005) Enkephalinimmunoreactive interneurons extensively innervate sympathetic preganglionic neurons regulating the pelvic viscera. J Comp Neurol 488:278-289. CrossRef Medline

Llewellyn-Smith IJ, Martin CL, Fenwick NM, Dicarlo SE, Lujan HL, Schreihofer AM (2007) VGLUT1 and VGLUT2 innervation in autonomic regions of intact and transected rat spinal cord. J Comp Neurol 503:741-767. CrossRef Medline

Loeser JD, Ward AA Jr, White LE Jr (1968) Chronic deafferentation of human spinal cord neurons. J Neurosurg 29:48-50. CrossRef Medline

Lorenzo LE, Magnussen C, Bailey AL, St Louis M, De Koninck Y, Ribeiro-daSilva A (2014) Spatial and temporal pattern of changes in the number of GAD65-immunoreactive inhibitory terminals in the rat superficial dorsal horn following peripheral nerve injury. Mol Pain 10:57. CrossRef Medline

Madisen L et al. (2012) A toolbox of Cre-dependent optogenetic transgenic mice for light-induced activation and silencing. Nat Neurosci 15:793802. CrossRef Medline

Miraucourt LS, Dallel R, Voisin DL (2007) Glycine inhibitory dysfunction turns touch into pain through PKCgamma interneurons. PLoS One 2:e1116. CrossRef Medline

Miyoshi G, Hjerling-Leffler J, Karayannis T, Sousa VH, Butt SJ, Battiste J, Johnson JE, Machold RP, Fishell G (2010) Genetic fate mapping reveals that the caudal ganglionic eminence produces a large and diverse population of superficial cortical interneurons. J Neurosci 30:1582-1594. CrossRef Medline

Moore KA, Kohno T, Karchewski LA, Scholz J, Baba H, Woolf CJ (2002) Partial peripheral nerve injury promotes a selective loss of GABAergic inhibition in the superficial dorsal horn of the spinal cord. J Neurosci 22:6724-6731. Medline

Moyer JR Jr, Brown TH (1998) Methods for whole-cell recording from visually preselected neurons of perirhinal cortex in brain slices from young and aging rats. J Neurosci Methods 86:35-54. CrossRef Medline

Mukhida K, Mendez I, McLeod M, Kobayashi N, Haughn C, Milne B, Baghbaderani B, Sen A, Behie LA, Hong M (2007) Spinal GABAergic transplants attenuate mechanical allodynia in a rat model of neuropathic pain. Stem Cells 25:2874-2885. CrossRef Medline

Munro G, Ahring PK, Mirza NR (2009) Developing analgesics by enhancing spinal inhibition after injury: GABAA receptor subtypes as novel targets. Trends Pharmacol Sci 30:453-459. CrossRef Medline

Paul J, Zeilhofer HU, Fritschy JM (2012) Selective distribution of GABA(A) receptor subtypes in mouse spinal dorsal horn neurons and primary afferents. J Comp Neurol 520:3895-3911. CrossRef Medline

Pinco M, Lev-Tov A (1993) Synaptic excitation of alpha-motoneurons by dorsal root afferents in the neonatal rat spinal cord. J Neurophysiol 70 : 406-417. Medline

Polgár E, Todd AJ (2008) Tactile allodynia can occur in the spared nerve injury model in the rat without selective loss of GABA or GABA(A) receptors from synapses in laminae I-II of the ipsilateral spinal dorsal horn. Neuroscience 156:193-202. CrossRef Medline

Potter GB, Petryniak MA, Shevchenko E, McKinsey GL, Ekker M, Rubenstein JL (2009) Generation of Cre-transgenic mice using Dlx1/Dlx2 enhancers and their characterization in GABAergic interneurons. Mol Cell Neurosci 40:167-186. CrossRef Medline

Proudlock F, Spike RC, Todd AJ (1993) Immunocytochemical study of somatostatin, neurotensin, GABA, and glycine in rat spinal dorsal horn. J Comp Neurol 327:289-297. CrossRef Medline

Riley RC, Trafton JA, Chi SI, Basbaum AI (2001) Presynaptic regulation of spinal cord tachykinin signaling via $\mathrm{GABA}(\mathrm{B})$ but not $\mathrm{GABA}(\mathrm{A})$ receptor activation. Neuroscience 103:725-737. CrossRef Medline

Schoffnegger D, Heinke B, Sommer C, Sandkühler J (2006) Physiological properties of spinal lamina II GABAergic neurons in mice following peripheral nerve injury. J Physiol 577:869-878. CrossRef Medline

Scholz J, Broom DC, Youn DH, Mills CD, Kohno T, Suter MR, Moore KA, Decosterd I, Coggeshall RE, Woolf CJ (2005) Blocking caspase activity prevents transsynaptic neuronal apoptosis and the loss of inhibition in lamina II of the dorsal horn after peripheral nerve injury. J Neurosci 25:7317-7323. CrossRef Medline

Shields SD, Eckert WA 3rd, Basbaum AI (2003) Spared nerve injury model of neuropathic pain in the mouse: a behavioral and anatomic analysis. J Pain 4:465-470. CrossRef Medline

Southwell DG, Nicholas CR, Basbaum AI, Stryker MP, Kriegstein AR, Rubenstein JL, Alvarez-Buylla A (2014) Interneurons from embryonic development to cell-based therapy. Science 344:1240622. CrossRef Medline

Takazawa T, MacDermott AB (2010) Glycinergic and GABAergic tonic inhibition fine tune inhibitory control in regionally distinct subpopulations of dorsal horn neurons. J Physiol 588:2571-2587. CrossRef Medline

Tamamaki N, Yanagawa Y, Tomioka R, Miyazaki J, Obata K, Kaneko T (2003) Green fluorescent protein expression and colocalization with calretinin, parvalbumin, and somatostatin in the GAD67-GFP knock-in mouse. J Comp Neurol 467:60-79. CrossRef Medline

Tanaka Y, Tanaka Y, Furuta T, Yanagawa Y, Kaneko T (2008) The effects of cutting solutions on the viability of GABAergic interneurons in cerebral cortical slices of adult mice. J Neurosci Methods 171:118-125. CrossRef Medline

Tricoire L, Pelkey KA, Erkkila BE, Jeffries BW, Yuan X, McBain CJ (2011) A blueprint for the spatiotemporal origins of mouse hippocampal interneuron diversity. J Neurosci 31:10948-10970. CrossRef Medline

Vogt D, Hunt RF, Mandal S, Sandberg M, Silberberg SN, Nagasawa T, Yang Z, Baraban SC, Rubenstein JL (2014) Lhx6 directly regulates Arx and CXCR7 to determine cortical interneuron fate and laminar position. Neuron 82:350-364. CrossRef Medline

West SJ, Bannister K, Dickenson AH, Bennett DL (2015) Circuitry and plasticity of the dorsal horn: toward a better understanding of neuropathic pain. Neuroscience 300:254-275. CrossRef Medline

Yasaka T, Tiong SY, Hughes DI, Riddell JS, Todd AJ (2010) Populations of inhibitory and excitatory interneurons in lamina II of the adult rat spinal dorsal horn revealed by a combined electrophysiological and anatomical approach. Pain 151:475-488. CrossRef Medline

Yoshimura M, Nishi S (1993) Blind patch-clamp recordings from substantia gelatinosa neurons in adult rat spinal cord slices: pharmacological properties of synaptic currents. Neuroscience 53:519-526. CrossRef Medline

Yoshimura M, Nishi S (1995) Primary afferent-evoked glycine- and GABAmediated IPSPs in substantia gelatinosa neurones in the rat spinal cord in vitro. J Physiol 482:29-38. CrossRef Medline

Zeilhofer HU (2008) Loss of glycinergic and GABAergic inhibition in chronic pain-contributions of inflammation and microglia. Int Immunopharmacol 8:182-187. CrossRef Medline 